Article

\title{
The Politics of Sex Abuse in Sacred Hierarchies: A Comparative Study of the Catholic Church and the Military in the United States
}

\author{
Carolyn M. Warner ${ }^{D}$ \\ School of Politics and Global Studies, Arizona State University, AZ 85287, USA; cwarner@asu.edu
}

Received: 28 February 2019; Accepted: 10 April 2019; Published: 20 April 2019

\begin{abstract}
The paper explores similarities in patterns of abuse and in patterns of how the known abuse cases are handled by the Catholic church and the U.S. military and develops preliminary explanations of why. The paper considers how the two organizations deal with external efforts by civil authorities at oversight and prosecution, and the extent to which they invoke their sacred status authority to evade responsibility and civilian oversight. The paper finds that the handling of sex abuse in each organization has been affected partly by the institutions seeing themselves as sacred, as something apart from the secular state, beholden to alternative authorities. The paper highlights the fact that child sex abuse by religious officials and sexual assault of soldiers by fellow soldiers and officers constitute profound challenges for democracy in the US and elsewhere, as the institutions claim and may be accorded separate and privileged status, beyond the reach of democratic laws and procedures. It is a warning about the costs of public deference to other institutions. The study utilizes documentation of Catholic church clergy child sex abuse cases in the US, and documentation of sex abuse cases in the US military.
\end{abstract}

Keywords: clergy child sex abuse; sexual assault; military; Catholic church; sacred; institutions

The response from the diocese was, 'How much do you want? Can we give you some money to shut up about all this?

Clergy child sex abuse victim ${ }^{1}$

The thing that makes me the most angry is not even the rape itself; it's the commanders that were complicit in covering up everything that happened.

Ariana Klay, U.S. Marine Corps ${ }^{2}$

Sexual harassment and sexual assault in the military are a profound betrayal of sacred oaths and sacred trusts.

U.S. Secretary of Defense Chuck Hagel ${ }^{3}$

[Clergy child sex abuse] is something more than despicable actions. It is like a sacrilegious cult, because these boys and girls had been entrusted to the priestly charism in order to be brought to God. And those people sacrificed them to the idol of their own concupiscence.

Pope Francis ${ }^{4}$

\footnotetext{
In (Balboni 2011, p. 85).

http://www.gillibrand.senate.gov/mjia/quotes.

Commencement Speech, United States Military Academy [West Point]. 25 May 2013. http://archive.defense.gov/Speeches/ Speech.aspx?SpeechID=1782.

47 July 2014. http://www.theguardian.com/world/2014/jul/07/pope-francis-catholic-bishops-child-paedophile-abuse-priestcondemn.
} 


\section{Introduction}

As the 2016 movie "Spotlight" publicized, in 2002 media investigations revealed that a Catholic priest in the Boston archdiocese had abused between 130 and 200 children over several decades, church officials knew of this, and yet continued to transfer him to new parishes whenever a case surfaced in his current parish (Globe 2002, p. 14). ${ }^{5}$ Other priests had abused hundreds more (Globe 2002, p. 3 and passim; Reilly 2003). ${ }^{6}$ Some victims later committed suicide. In 2014, a report by Minnesota Public Radio revealed that even after prosecutions and expensive litigation in civil courts and negative publicity surrounding earlier cases across the country, the leadership of the Catholic Archdiocese of St. Paul and Minneapolis still was engaging in the same kind of behavior the Boston officials had a decade and more earlier (Minnesota Public Radio 2014; Nienstedt 2014). Subject to extensive secular scrutiny, including by the United Nations, the Catholic church has been forced to address clergy child sex abuse and its handling of the issue and the cases. Indeed, in some countries, bishops initiated reforms (Irish Catholic Bishops' Advisory Committee on Child Sexual Abuse by Priests and Religious 1996; O'Reilly and Chalmers 2014, pp. 283-86; Senander 2017; Truth and Council 2018a, 2018b, 2018c, vols. 1-3; Truth and Council 2016; United Nations Committee on the Rights of the Child 2014). Yet, as is evident in the Minnesota cases, and in the underwhelming outcome of its 2019 Vatican meeting on child sex abuse, the church has a long way to go (National Catholic Reporter Editorial Staff 2019).

In 1992, the US Navy's Tailhook scandal brought attention to extensive sexual harassment in the US military services. In 1996 reports surfaced that drill sergeants at the Army's Aberdeen Proving Grounds had been raping female recruits. In 2011, the same problem came to light at Lackland Air Force base in Texas, and in 2017, at the Army's Fort Benning. ${ }^{7}$ In 2003 and multiple years afterwards, sexual assaults at the US Air Force Academy and during the Iraq War received Congressional attention. The assaults sometimes resulted in the victim's death. After a flurry of strident calls to order by Secretaries of Defense and Commanders in Chief, starting in 1992, the problem seems to have become entrenched. A 2016 Department of Defense (DoD) funded survey estimated that about 14,900 active duty service members, or about $1.2 \%$ ( $4.3 \%$ women, $0.6 \%$ men), had been sexually assaulted with the previous twelve months (Office of People Analytics 2017, p. ix). While Congress has compelled the military to make changes in how it handles sexual assaults, including in prevention, the military has recently seen the Army's top sex crimes prosecutor himself accused of sexual harassment, and a Sexual Assault Prevention and Response officer pimping US women soldiers. ${ }^{8}$ To quote a Washington Post headline from 2015, when it comes to dealing with sexual assault, the military "keeps shooting itself in the foot" (Whitlock 2015).

Complaints of the victims about how their cases were handled, whether in the military or in the church, have been of a similar tenor. Responses of the organizations have also been strikingly similar to each other. In short, the military and the Catholic church have prioritized the interests of the institution over the interests of the victims, claimed their legal and administrative systems were sufficient to handle the issue, at times been callous towards alleged victims, and had conflict of interest problems in investigating and prosecuting cases. In defense of their actions, both institutions have pointed to their distinct missions. The words of Defense Secretary Hagel and of Pope Francis point to something sacred being violated when sex abuse occurs in the institutions. Hagel and Francis also have had made strong statements about reducing the extent of the problem. Yet despite their words, despite the violations

5 Ford, et al. v. Bernard Cardinal Law, et al. 2003. 02-1296, Superior Court Department, Suffolk County Civil Action No. 02-04551-T1 (Consolidated with C.A. 02-1296). Commonwealth of Massachusetts. (July 21). http://s3.documentcloud.org/ documents/250308/11-boston-pattern-and-practice-text-and.pdf, p. 83.

6 The first widely publicized case of clergy child sex abuse in the US was of Father Gilbert Gauthe, of Louisiana (Berry 1992).

7 "Drill sergeant" is a colloquial term; the military's formal term is military training instructor (MTI).

8 The alleged assault of a female Army lawyer by Lt. Col. Joseph Morse occurred at a sexual assault law conference (Carroll and Vandiver 2014). Also in 2013, Sgt. 1st Class Gregory McQueen, a victim's advocate in SAPRO, was found to be running a prostitution ring (pimping female soldiers) at Fort Hood, Texas. In 2015, he was sentenced to two years in prison and given a dishonorable discharge. 
of the sacred that have occurred in both institutions, the problems continue. Why are their words so powerless? This paper explores whether the presumed sacredness of the institutions has been a factor.

Scholarly studies of the reactions of officials in the Catholic church and US military to claims by victims, and to claims by civil society that changes must be made, have focused separately on each institution. As the quotations at the beginning of this paper reflect, there are some striking similarities (Katzenstein 1998). This paper is an initial effort to compare and account for how the institutions have handled sex abuse cases and how they have reacted to public outcry and public authorities' efforts to rein in the problem. It may not only be the case that because these are closed, male-dominated hierarchical bureaucracies, they resist external pressures to reform and fall short in reforming themselves. Clearly, these factors have been significant (Archer 2013; Belkin 2012; Cossins 2000; Crozier 1964; Goffman 1961; Keenan 2012; Doig et al. 1984; Vaughan 1996; Wilson 1989). In addition, and strikingly, both institutions, not just the Catholic church, make claims to a separate and sacred mission, giving themselves a sacred or quasi-sacred status that leads their officials to discount the problem, and insulates the institutions from the control of external authorities and citizens.

Sex abuse occurs in all kinds of organizations; universities are a recent focus of scandal and of U.S. federal government inquiry, for instance, and the Boy Scouts have come in for scrutiny as well. Other religions are not immune to their religious officials sexually abusing minors (Aviv 2014; Neustein and Lesher 2008; Arnold 2008, pp. 857-65; Royal Commission on Institutional Responses to Child Sex Abuse 2017). While the church and military have different purposes, comparing them puts into stark relief a set of factors that may make addressing the issue more difficult: they have their own judicial systems, they have a very strong code of silence (Katzenstein 1998, pp. 47, 134), they heavily prioritize the hierarchical institution over the individual, they appeal to a higher calling, they are male-dominant, their victims cannot easily leave them, and they have a strong view of their unique and sacred or quasi-sacred status, a status that has often been respected and reinforced by the civilian/secular state.

Sexual assaults committed by soldiers against civilians have been a significant topic of recent study by political scientists (Cohen and Nordhås 2015; Wood 2009); that of soldiers against their fellow soldiers has received far less attention (Ellner 2015; Wood and Toppelberg 2017). ${ }^{9}$ Clergy child sex abuse in the Catholic church, and religious institutions more generally, has also been largely overlooked in political science, instead being studied mostly by psychologists, criminologists and legal scholars (but see Formicola 2004, 2007, 2011, 2014, 2016). Studies by political scientists on religious liberty have not examined the consequences of that liberty for how organized religions handle child sex abuse by their officials (Gill 2008). Studies of the military and politics have not broached the topic of sexual assault either (Feaver and Kohn 2001; Dempsey 2010). As Katzenstein wrote, these are "major illiberal institutions in a liberal state" (Katzenstein 1998, p. 196). Yet how both institutions have handled sexual assault and have been allowed by public authorities to handle it raises questions of political accountability of highly gendered institutions that have been treated with reverence. Furthermore, the impact of sexual assault and abuse can have life-long devastating consequences for victims, and when authorities do not hold perpetrators responsible, many offenders are likely to repeat their actions with the same or new victims (Lisak and Miller 2002). To address sexual violence in the Catholic church and military, it is essential to understand why they have handled the problem as they have, as well as the consequences of the state having granted them wide latitude to handle it themselves.

One can go far with an argument based on bureaucratic politics and on gender. My point is that the dynamics of bureaucratic politics and gender likely are heightened in sacred institutions, including that they have been granted substantial autonomy to handle sex abuse on their own terms. While it's true that sex abuse is a problem in a wide range of institutions, a focus on these two is useful for the features the comparison highlights, and for the fact that these are two very prominent institutions that

9 Katzenstein and Reppy (1999) examines sexual harassment by way of discrimination in the military. 
for a time have been resistant to civilian efforts to get them to rectify problems. They have often been granted a considerable amount of deference to handle cases of sex abuse internally, with harsh results for victims and for preventing future abuse.

The paper proceeds as follows. It briefly describes the problems with clergy child sex abuse and sexual assault in the church and military, respectively. It then juxtaposes the two institutions and how they have handled cases, identifying similarities between the two, and highlighting the effect of the quasi-sacred hierarchical structures on their actions. It next explores the role of the sacred in civil authorities' and the public's responses. In the conclusion, the paper considers why the church has become more responsive to the victims and to civil authorities. To preview, where the church and military diverge most obviously is also where the politics enters most clearly: legal authorities, in many instances, have determined that the church is, in some way, liable and subject to lawsuits for priests and that priests' criminal activity is indeed subject to criminal and civil law, not just canon law, whereas legal authorities have held that the military has no responsibility. Indeed, rape is "incident to service."10 Ironically, this comes at a time when rape and other forms of sexual violence by soldiers against civilians are no longer considered just typical costs of wartime conflict, but as prosecutable war crimes (Benedict 2009; Chappell 2014; Durbach and Chappell 2014). Paradoxically, although the church would seemingly benefit from First Amendment protections, it and its officials have been successfully sued and priests jailed, whereas the military, answerable to Congress and officially led by the US President, faces no such external legal action. The paradox points to the extent to which the institutions' actual autonomy benefits from the deference accorded them by civil authorities. The evidence largely comes from government reports, Congressional hearings, law enforcement investigations, court records, church records, and media investigations. ${ }^{11}$

\section{Definitions and Scope}

Before proceeding further, it is useful to clarify some terms. The child sex abuse scandals of the Catholic church are often discussed in the media and by church officials as cases of "pedophilia". The term is something of a misnomer. Pedophilia refers to a specific condition of "persistent attraction to or molestation of pre-pubescent children" (Cartor et al. 2008, p. 311). Most of the victims of "pedophile priests" are children between the ages of eleven and seventeen (John Jay College of Criminal Justice 2004, pp. 53-54; John Jay College Research Team 2011, p. 11). Because of this, and following the practice of other scholars (e.g., Formicola 2004, 2007, 2011; Keenan 2012; O'Reilly and Chalmers 2014), I use the term "clergy child sex abuse".

The term sexual assault is more often applied to sexualized attack on an adult and thus is more often used than "sex abuse" in discussing sexual violence in militaries. As the U.S. General Accounting Office has summarized, in the U.S. military, "[s]exual assault includes rape, forcible sodomy (oral or anal sex), and other" sexual contact to which there has not been consent "that is aggravated, abusive, or wrongful", or "attempts to commit these acts" (United States Government Accountability Office 2011, p. 8; Stander and Thomsen 2016). This usage informs this paper. It does not include "unwanted" sexual contact to which there was consent (Legal Information Institute n.d.).

Because it is not always confirmed legally whether a sexual assault or child sex abuse occurred, the paper uses a variety of terms to denote the apparent victim, such as victim, alleged victim or accuser interchangeably. The paper uses the term "victim", rather than "survivor", knowing the term "victim" is a sensitive one for those who have been victims of clergy child sex abuse or of sexual assault in the military. This is in keeping with legal terminology. It maintains consistency in the paper and

10 Cioca v. Rumsfeld, United States Court of Appeal for the Fourth Circuit. 12-1065 (2013); Dynes v. Hoover 61 U.S. 65, 1857, pp. $15-24$.

11 To reduce wordiness, I use the term, "the military", rather than listing the Army, Navy, Air Force, Marines and Coast Guard, and their subunits, separately. 
allows for the fact that some of the victims were killed by the abuse. It is not intended that the term as used in this paper denies their agency nor passes judgment on their status.

The paper is not a study of what motivates certain individuals in the military or priesthood to commit sexual assault of fellow soldiers or of children, respectively, nor an evaluation of the impact of sex abuse on the victims. It is not trying to evaluate the effectiveness of particular training, prevention, or awareness programs implemented by the military or the church. These topics warrant their own focused analyses.

Finally, to keep the background legal, political and cultural factors similar for the two institutions, this paper focuses upon the Catholic church in the US and on the US military. A substantial cross-national study is the next step in the larger research project. Similar dynamics within the two kinds of institutions appear to have obtained in other countries, as numerous official inquiries have shown (e.g., Royal Commission on Institutional Responses to Child Sex Abuse 2017; Commission of Investigation 2010; Reilly 2003; Ministère de la Défense 2014; Rumble et al. 2011).

\section{Background}

The only comprehensive study of the frequency and extent of Catholic clergy child sex abuse finds that, between 1950 and 2002, approximately 5\% of clergy in the U.S. have sexually abused children, with a frequency ranging from once to hundreds of times (John Jay College of Criminal Justice 2004, p. 29), and that approximately 50,000 children in the US overall have been sexually abused by a Catholic clergy member one or more times during that time period. ${ }^{12}$ While there are debates about whether these statistics are "better" or "worse" than what occurs in the general population, that is beside the point for both the victims and for a consideration of how the church has handled the problem. The latter has been a scandal of enormous proportions for the church, leading to the bankruptcy of, at the time of writing, twelve dioceses in the US, the jailing of dozens of priests, legal settlements totaling almost three billion dollars just since 2004 (O'Reilly and Chalmers 2014, pp. 4, 74), a substantial drop in Catholic charitable donations to their churches, and an exodus of many laity (Catholics) from the church (Hungerman 2013). ${ }^{13}$

As is well-known by now, the Catholic church in the U.S. has often ignored or covered up its numerous cases of clergy child sex abuse. As a report by the Massachusetts Attorney General in 2003 stated, "widespread abuse of children [by Catholic clergy] was due to an institutional acceptance of abuse and a massive and pervasive failure of leadership" spanning at least "fifty years" (Reilly 2003, pp. 2, 16). In scores of dioceses, bishops knowingly transferred child sex abusing clergy around parishes in their dioceses, ignored deviant behavior, and did not report abuse suspicions to police. Some bishops stated, even as recently as 2009, that they couldn't be bothered with the issue. ${ }^{14}$ In the instances when the hierarchy temporarily removed a priest from parish service, they sometimes put the accused priest in charge of programs to monitor child sex abusing priests (Reilly 2003, p. 38). Reforms in church procedures for investigating cases have not changed structures and incentives. ${ }^{15}$

12 The study was sponsored by the U.S. Conference of Catholic Bishops. "Child" was anyone below age 18 when abused. Between 1965 and 2014, the self-declared Catholic population in the US has gone from 48.5 million to 78.7 million. The church is organized geographically into 178 Latin rite dioceses and archdioceses, and 17 Eastern, with about 17,500 parishes within them. Numbers of priests have ranged from almost 59,000 in 1965 to just over 38,000 in 2014. Practicing Catholics are expected to attend the parish in which they reside and most do (http://cara.georgetown.edu/caraservices/requestedchurchstats.html; Gamm 1999). Most abuse cases occur years before the victim is able to report, and thus are often past the statute of limitations for criminal prosecution, as well as past the church's under canon law.

13 Bankruptcy has, however, been used by some dioceses to reduce financial compensation to victims and to freeze pending litigation ( $\mathrm{O}^{\prime}$ Reilly and Chalmers 2014, pp. 4, 27).

14 State of Minnesota v. the Archdiocese of Saint Paul and Minneapolis. No. 2139124-1 (2015), p. 17.

15 State of Minnesota v. the Archdiocese of Saint Paul and Minneapolis. No. 2139124-1 (2015), pp. 26-29. 
The pattern is similar in the military. ${ }^{16}$ On 12 July 1991, Secretary of Defense Dick Cheney sent a memo to the Chairman of the Joint Chiefs of Staff, Secretaries of the Military Departments, and others stressing a zero tolerance policy for sexual harassment. Leaders were instructed to "[m]ake prompt, thorough investigation and resolution a priority in every sexual harassment complaint" (reproduced in U.S. House of Representatives Military Personnel and Compensation Subcommittee and Defense Policy Panel of the Committee on Armed Services 1992, p. 57). Evidence indicates that change has been slow: abuse and assault persist, and the ways the military handles cases often seem to prioritize the career of the accused or reputation of the institution (U.S. Senator Kirsten Gillibrand 2015; Human Rights Watch 2015). Many accused remain in service, having received little or no punishment; some get promoted. Rates of perceived retaliation against alleged victims are high, over $60 \%$, although low reporting rates have moved upwards somewhat and a strong majority of those reporting have been satisfied with how their cases were handled (Department of Defense Sexual Assault Prevention and Response [United States] 2015, pp. 7, 10-11). Cases of high ranking commanders not taking reports and evidence of sexual assault seriously still surface (Whitlock 2014, 2017). Despite the military's mantras of "zero tolerance" and "good order and discipline", it often appears that there is a de facto tolerance of sexual assault, undermining good order and discipline (U.S. Senate Subcommittee on Personnel, Committee on Armed Services 2013, p. 111; Wood and Toppelberg 2017).

How did these institutions arrive at this point? A comprehensive analysis of the likely multiple contributing factors is beyond the scope of this paper. The more modest goal here is to explore the way in which the institutions' sacred status may have affected how the institutions responded to internal cases of sex abuse.

The sacred is something that is viewed with reverence and venerated by a community. It is a socially constructed attribute the status of which may change over time. A sacred entity is usually assumed to have a transcendent, a-temporal quality, that gives it unquestioned authority (Hassner 2009; Lincoln 2003, pp. 5-7). It is sacrosanct, meant to be immune from criticism and violation. It contrasts with the profane, the mundane and humanly inspired.

Sacred status has several features that seem to have contributed to institutional mishandling of sex abuse cases. First, the two institutions' bases of authority derive in large part from their sacred status. Religion is a "credence good", one for which the validity of its promises is usually hard to discern (Gill 2008, p. 50). The military's promise of defense of the nation being something worth sacrificing one's life for is also hard to render tangible or verifiable (Ebel 2015). Because the institutions rely on individuals volunteering to consecrate their lives to the institution, the importance of the institution being a pure and worthy cause is heightened. Accusations of something as vile as clergy child sex abuse and sexual assault by fellow soldiers undermine that image, making it more likely abuse events are discounted, not believed, or covered-up. Combined with the fact that those in the institution are viewed as above reproach, and, for the church, literally holy, officials in the institutions may not see abuse. It can take a long time for those in authority to recognize that there is a problem. Third, the institution views itself as having the right to handle the issue itself, with no intervention. In addition, to sustain the sacred image, external authorities and the lay and civilian public should not know that such abuse is occurring. There is thus considerable pressure to hide the abuse from external authorities and the public. Having sacred status can help insulate an institution from challenges to its authority, from external intervention.

\section{Sacrosanct Hierarchical Structures and Legal Systems}

Students of bureaucracies would find little unusual in the behavior of the church and the military, once they took into account the strictly hierarchical and insular structures of the two institutions

16 The military has gone from approximately $11 \%$ women in Active Duty status in 1990 (out of a total of 2,043,000) to about $16 \%$ in 2017, out of a total of about 1,344,000 Active Duty personnel (Department of Defense [United States] 2010, p. 19). 
(Crozier 1964, pp. 179, 195; Goffman 1961). Yet the effects of those structures are, I would argue, aggravated by the seemingly unassailable, immutable sources of the structures: autonomous governing systems, with one believed ordained by God, the other by the nation.

\subsection{Catholic Church}

Catholic theology, codified in canon law, informs the church's hierarchical structure. It deems religious officials separate and superior to the laity. There is "no separation of powers" (O'Reilly and Chalmers 2014, p. 208). Within the church, there are no formal checks on the pope's powers (Doyle and Rubino 2004, p. 558). A diocesan bishop, appointed to his diocese by the Pope, holds executive, legislative and judicial power in his diocese, subject only to the Pope and the Code of Canon Law (O'Reilly and Chalmers 2014, pp. 200, 208; Formicola 2014, pp. 75-110). Bishops have substantial control over the assignments of priests in their dioceses. Bishops, in turn, have a strong view that for the governance of their dioceses, they answer to the Pope alone, not to civil authorities, even as they may advocate for some changes to Papal policies. As the Bishop of Phoenix stated at a news conference during which he rejected the facts in the immunity agreement he had just signed, "I serve at the pleasure of the Pope, and not the County Attorney" (Arizona Republic 2003).

Until the promulgation of the first consolidated Code of Canon Law, in 1917, church canons stipulated that priests whom the church found guilty of child sex abuse were to be turned over to civil authorities. During the church-state battles of the late 19th and early 20th centuries flaring in Europe, the church internalized its handling of clergy child sex abuse. Priests were not to be handed over to civil authorities, and, as of 1922, investigations of clergy suspected of abusing children in the confessional were to be cloaked in secrecy (Tapsell 2014). The problems were to be kept in-house. Further, the punishment of automatic dismissal from the clerical state (often referred to as "laicization" or "de-frocking") became optional, to be used only after it was determined that there was no possibility of reform.

The 1983 Code, as with the 1917 Code, has canons related to sex abuse. Canon 1387 defines using confessional to solicit sex as a crime (a delict), and 1395 makes it a crime when the same is done with a minor. The focus is on the priest violating his promise of chastity and abusing the confessional, not on the abuse perpetrated on a minor. Under the 1917 Code, bishops, under certain conditions, could dismiss priests from the clerical state, and without a canonical trial. The 1983 revision to the entire Code made that impossible. While it appears Pope John-Paul II was responding to a wave of priests abandoning the priesthood, the effect was that just as the numbers of cases of clergy child sex abuse were rising, bishops were constrained by the new edict to retain abusive priests unless the latter were found guilty at a canonical trial and the Vatican, officially, the pope, agreed to dismiss them (O'Reilly and Chalmers 2014, p. 258). At best, bishops could suspend priests' clerical faculties for a time, but not permanently.

Canon law has other consequences for the church's handling of clergy child sex abuse. As in the 1917 Code, the 1983 Code of Canon Law stipulates that bishops are first to try "fraternal correction or rebuke or other means of pastoral solicitude" and only if those "cannot sufficiently repair the scandal, restore justice, reform the offender" may the bishop resort to an administrative penalty or judicial (canonical) trial (Vatican 1983, Code 1341). Canonical trials are complex, have considerable due process protections for the accused, and require the cooperation of the victim as a witness. Since 2001, in a further centralizing move, the Vatican has required that bishops send all cases of substantiated allegations of child sex abuse the Congregation for the Doctrine of the Faith to review. The CDF may tell the bishop to conduct a canonical trial, may conduct one itself, or may accept or reject a request for dismissal, and apply conditions (Richardson 2011). Priests can appeal the verdicts and sentences, and the Vatican has overruled bishops on legal technicalities.

The 1917 and 1983 codes tended to reinforce the church's perceived autonomy from the civil state. The church has regarded itself as having the authority to be in charge of itself and its religious officials and to deal with any matters arising from their behavior (Formicola 2014, p. 196; 
Nash 2019, p. 10). Stemming from early medieval times, the church has long claimed, and often been granted, the privilege of trying priests within its own court system rather than allowing civil authorities to try them. Bishops have relied on the church's internal procedures and norms (Nienstedt 2014; Weakland Deposition 2011, pp. 23-25). In explaining the rather confusing conditions under which he can remove a priest, Cardinal Francis George of Chicago said, "Within the process and the norms, a bishop must obey the rules of the church. We're all in a society of law in the church too" (George Deposition 2008, p. 274).

For the church, the sanctity of the seal of confession has contributed to its not having reported child sex abuse to civil authorities (Lytton 2008, pp. 68-69; O'Reilly and Chalmers 2014, pp. 78-79; Waters 2016). ${ }^{17}$ Bishops and priests, if they hear of the abuse during a priest's confession, or in a context regarded as counseling, view the matter as sealed. Additionally, starting with Pius IX in 1922, successive Popes, as late as 2010, have declared that the "pontifical secret" applies to clergy child sex abuse cases, blanketing those cases with "permanent silence" even outside the context of the confessional (Tapsell 2014). Although it is entirely within his power to do so, Pope Francis has not altered those rules (Tapsell 2015). The shielding of a crime by church officials is a collateral effect of their adhering to the church's theology and legal structure.

For clergy child sex abuse or other infractions, if word gets reported up to the bishop of the diocese or head of the order, the bishop then decides whether to investigate the allegations. If he decides to, he appoints the investigators, then, when he gets their report, decides whether there are grounds for doing anything (O'Reilly and Chalmers 2014, pp. 343-44, 347; Doyle and Rubino 2004, pp. 556, 558). ${ }^{18}$ And if the decision is to have a canonical trial or otherwise try to laicize the priest, the Vatican is the final arbiter. These powers are similar to those of US military commanders, as we will see. Even if a priest is found guilty in a canonical trial, he is not subject to automatic removal from the priesthood (laicization). The Vatican has final disposition authority. A guilty verdict in a secular criminal trial does not oblige the church to likewise "convict" the priest or remove him from the priesthood. Since 2001, the Vatican has required that all cases of substantiated allegations of child sex abuse be sent to its Congregation for the Doctrine of the Faith to review (Tapsell 2014, p. 27). One issue is that often bishops have not judged allegations to be substantiated. In some cases in which they have, however, because of the onerous procedures, and the risks bishops run of being overturned by the Vatican, bishops have offered offending priests funds to help with the transition to lay life, provided they laicize voluntarily (Archdiocese of Milwaukee n.d.; Weakland Deposition 2011, p. 224; Henry Files 1997, RCALA005286; Schenck 2014). Doing so is also in keeping with a sacred obligation (Vatican 1983, Code 1350). Summing up the situation, the Massachusetts Attorney General observed that "The process protects priests at the expense of victims and, in the final analysis, is incapable of leading to timely and appropriate responses to sex abuse allegations" (Reilly 2003, p. 18; cf. Suffolk County Supreme Court Special Grand Jury 2003; Heed et al. 2003).

\subsection{US Military}

Military doctrine and purpose create an institution that, like the Catholic church, is and sees itself as unique and distinct from civil society and government. So that the military can carry out its authorized mandate of killing in the name of the country, it has to have special rules to render lawful what in other

17 Ford, et al. v. Bernard Cardinal Law, et al. 2003. 02-1296, Superior Court Department, Suffolk County Civil Action No. 02-04551-T1 (Consolidated with C.A. 02-1296). Commonwealth of Massachusetts. (July 21). http://s3.documentcloud.org/ documents/250308/11-boston-pattern-and-practice-text-and.pdf, p. 44.

18 Since 2002, many dioceses have set up review boards, of members appointed by the bishop, to help investigate. They may supplement the work of legal counsel, and they often do not get full information about cases. Their work is advisory, and has been criticized for being biased in favor of the accused (Commonwealth of Pennsylvania, Office of Attorney General 2016, p. 123; De Fuentes 2004). Furthermore, the victims themselves are often investigated, rather cruelly, by a person with the misnomer of "victim assistance coordinator" (Statewide Investigating Grand Jury, 40th, Pennsylvania 2018; County Investigating Grand Jury XXIII 2011, pp. 6-8; O’Reilly and Chalmers 2014, p. 314). 
contexts would be clearly unlawful. This creates a strong need for the soldier at war-the one authorized to kill—to be supported by a cohesive, tight unit of fellow soldiers, by the commanding officers who are directing the solider, and by the military as a whole. Faith in each level of support is quasi-religious and necessary to serve the flag and protect the Constitution. This faith was summarized by Marine Commandant James F. Amos, "I think command climate is the single, [in] my perspective, is the single greatest indicator not only for the combat readiness, the equipment readiness, the personnel readiness of the unit, all of those things, but also the health, what we call the spiritual health of that institution. I am not talking religion here. I am talking about the ability to be able or the absolute sacredness of taking care of one another" (U.S. Senate Committee on Armed Services 2013, p. 81). US Senator Martha McSally (R-AZ), a former commander in the US Air Force, described the relationship between commanders and their units as being quasi-religious: "Commanders also have a covenant with the men and women under their command" (U.S. Senate Committee on Armed Services 2019, p. 10). The command structure is strictly hierarchical, and is tasked with ensuring "good order and discipline" for combat readiness (Morris 2010, pp. 2-12, 52, 58). Like the Catholic church, the military has core values, extensive rituals, uniforms, and codes of conduct that are quasi-religious and include religious language (Carlson 2008, pp. 93-94). They serve the purpose of instilling discipline, commitment, selflessness, honor and respect. They inevitably also make the military an entity apart from civil society and other government entities. A soldier's commitment is regarded as sacred, not merely transactional (U.S. Senate Committee on Armed Services 2013, p. 43, 189; U.S. Senate Committee on Armed Services 2019, p. 70). ${ }^{19}$

US military law forms the basis of a structure that is meant to provide the Commander-in-Chief and subsidiary commanders with the ability to "aid [them] in properly commanding the army and navy and enforcing discipline therein" (Winthrop 1920, p. 49). Military justice is derived from powers of the President and Congress, not the judiciary. ${ }^{20}$ Military law is codified in the Uniform Code of Military Justice (UCMJ), promulgated in 1950 but many parts of which were in military law even at the time of the Continental Congress (Weigley 2004). General Raymond T. Odierno, Army Chief of Staff (2011-2015), explained: "I would just say that I think what we do in the military is very unique. We are asked to do things that are very different than any other profession, and that is why the UCMJ was originally created, for us to have this unique relationship because of the good order and discipline that we often talk about and the unit cohesion that is necessary to do the things that we are asked to do" (U.S. Senate Committee on Armed Services 2013, pp. 45-46). He could just as well have quoted (General) George Washington, "Discipline is the soul of an army. It makes small numbers formidable; procures success to the weak, and esteem to all" (29 July 1757, in (Alleman 2006)).

Unit commanders and the chain of command are the crux of the military justice system's operations. The formal procedures for handling sexual assault cases have been modified slightly in recent years, but the basic process is one in which, if an unrestricted report of a sexual assault is made (and that includes an attempt at sexual assault), the unit commanding officer is supposed to have the relevant service branch investigative unit (e.g., NCIS for the Navy and Marines) start an investigation. Since 2005, alleged victims and third parties have had multiple reporting options: the unit commander need not be the one to whom the report is made; however, the unit commander is responsible for launching an investigation. Once the investigative unit has completed its work, it conveys the report to the commanding officer of the accused, who decides, with advice from legal counsel (usually a Judge Advocate General, JAG) how to dispose of the case. The commander has a number of options, more so than a public prosecutor in a similar case. If the commander refers the case to court-martial, the commander becomes the "convening authority" and thus has the power to select the jury. In deciding whether to go forward with a case to court-martial or make another disposition, commanders are required to take into account possible effects on unit discipline, order and accountability. If the case

19 http://www.army.mil/values/oath.html; http://www.army.mil/values/song.html.

20 Dynes v. Hoover 61 U.S. 65, 1857. 
goes to a court-martial, the commander (convening authority) can, now subject to certain conditions, overturn a guilty verdict of the jury and/or reduce or eliminate the penalty imposed, if there was one (DoD 576 Panel 2014, p. 144; Joint Service Committee on Military Justice 2012, Art. 60).

The investigation, and any hearing and court-martial proceeding are only advisory to the commander-a means of providing information that helps the commander decide how to handle a particular case in light of the need for "good order and discipline". The commander's power over a case prompted one rape victim to wonder what the point of the judicial process was: "why don't we just write a letter and send it to the Commander who makes a unilateral decision?" (U.S. Senate Subcommittee on Personnel, Committee on Armed Services 2013, p. 164). Commanders basically adjudicate the proceedings (Alleman 2006). The potential for bias and the conflict of interest is obvious. One military rape victim made the point succinctly: "Having someone in your direct chain of command doesn't make any sense. It's like getting raped by your brother and having your dad decide the case" (Sarah Plummer, in Congressional Record Senate s8300 20 November 2013). The conflict of interest problem is compounded when, as in an estimated $60 \%$ of cases, the accused is in the alleged victim's chain of command (RAND 2015; cf. U.S. House of Representatives Committee on Armed Services 2013, p. 42). Cases of high-ranking officers failing to initiate investigations, or of proceeding with lesser charges than the investigators recommend, or of overturning convictions, keep surfacing, suggesting there is a bias in the military that has been hard to shift (Carpenter 2016).

The role of the military's chain of command structure in undermining the "zero tolerance" the leadership speak of is clear in the testimony of a male victim, who had been raped: "I was ordered by my command not to report this crime" (U.S. Senate Subcommittee on Personnel, Committee on Armed Services 2013, p. 14). The conundrum for the victim is clear: disobeying an order is unthinkable. There is a further conundrum due to the chain of command structure: if the leadership speaks out forcefully about preventing and prosecuting sexual assaults, it risks "unlawful command influence" (Morris 2010, pp. 141-42). When, in 2013, US President and Commander in Chief Barak Obama stated at a news conference that he had "no tolerance" for sexual assaults in the military and that "I expect consequences," a military judge ruled that Obama's statements constituted "unlawful command influence" and thus required a watering down of penalties should two defendants be found guilty of sexual assault (Slavin 2013). ${ }^{21}$ Filings in the case also cited statements of several defense secretaries as constituting unlawful command influence (United States v. Ernst Johnson 2013). Other military judges indicated they, too, would likely consider this (Slavin 2013). While some generals have said these statements have led them to realize they needed to act on cases (U.S. Army Inspector General Agency 2013, p. 28), the perception of unlawful command influence can lead to unintended outcomes. Marine Commandant General James Amos' speeches at Marine Corps bases denouncing sexual assault in the military have led to the overturning of a rape conviction and appeals of dozens of others on the grounds that Amos' speeches constituted "unlawful command influence" (Doyle 2012; Seck 2014; Rustico 2016, pp. 2051-54).

In attempting to deflect Congressional intervention in the authority of the chain of command, generals have invoked the special role of the UCMJ in the country's history, eliding it with a near-sacred purpose. In a Congressional hearing, Air Force Chief of Staff, General Mark A. Welsh III, stated, “The UCMJ traces its roots to the 1775 Articles of War, with 238 years of proven history and combat effectiveness behind it. During the intervening 238 years, this body of law-with commanders serving in a 'gate-keeping' role over courts-martial-has ensured a well-disciplined military, one that has fought the Nation's wars and defended national interests extremely well" (U.S. Senate Committee on Armed Services 2013, p. 48). The conflation with the founding of the country elevates the UCMJ to sacred status.

21 United States v. Ernest Johnson. Department of the Navy General Court-Martial Navy-Marine Corps Trial Judiciary Hawaii Judicial Circuit (2013), p. 3. 
As with the church arguing its structure and laws are sufficient, the military argues the UCMJ and the chain of command are sufficient to handle the problem of sexual assault. In his Congressional testimony about multiple rapes at Lackland Air Force base involving potentially 32 instructors and 59 victims, General Welsh stated "We have a structure. We have the ability to command and control and educate and train and oversee, and we have the ability to punish. We have all the tools in place to be the role models for this [effort to reduce sexual assaults in the military]" (U.S. House of Representatives Committee on Armed Services 2013, p. 25, cf. p. 12). Admiral Jonathan Greenert, Chief of Naval Operations, repeated the mantra in his Congressional testimony a few months later: "I think we have the tools, that the commander has the tools, we have the tools to provide a proper atmosphere of dignity, respect, and make sure the command climate is there" (U.S. Senate Committee on Armed Services 2013, p. 73; Judicial Proceedings Panel 2014, pp. 158, 162, 165, 178, 212, 217). These are the same statements that military leaders have said after earlier scandals and ensuing Congressional investigations, all pushing back against external intervention (U.S. House of Representatives Military Personnel and Compensation Subcommittee and Defense Policy Panel of the Committee on Armed Services 1992, p. 19; cf. U.S. House of Representatives Committee on Armed Services 1994, pp. 109-10).

The military's hierarchical control structure is similar to that which created serious problems in the Catholic church's response to child sex abuse by clergy. There are no horizontal checks on the commander, or "chain of command". One might say the horizontal checks for the military come from the outside, that is, civilian control. Yet the courts and Congress largely defer to the military. While it is often said that this is just a rational decision based on the functional needs of the military, the fact that other countries have made changes to their military justice systems of the sort proposed by Senator Gillibrand, suggests that other factors are at play (Law Library of Congress 2013).

\section{Sacred Status of the Perpetrator}

\subsection{Catholic Church}

Priests, when ordained, take on a different status (Guido 2008; Nash 2019, p. 7). They are now the sacramental ministers of God, and even if laicized for violations of canon law, still are viewed by the church as sanctified. Theology dictates that the vocation of priesthood is permanent and "indelible" (Catholic Church 1999, p. 1121; Keenan 2012, pp. 42-43; Tapsell 2014, p. 51). Priests and bishops are supposed to be celibate, and they typically live in facilities owned by their parish, diocese, or a religious order. Priests are further distanced from civil society by a vow of obedience to their bishop when ordained. This, and the sacrifices they make to become priests, creates a strong norm of loyalty amongst those officials towards one another (Cozzens 2002) and has likely contributed to the lengths to which the church has gone to protect priests at the expense of the victims. As one abuser, Father James Porter, eventually sentenced to twenty years in prison and who had resigned from the priesthood, said of his status outside the church: "Now there is no shield. I know that if I become familiar with children, people would immediately become suspicious ... In the lay life, I find out of necessity that I must cope with the problem or suffer the consequences" (in Globe 2002, pp. 44-45).

The church's tendency to protect accused priests is often blamed on "clericalism", though a comparison with the US military shows the pattern not unique to church-the military has a "clericalism" of its own. One bishop explained, "... our priests are incardinated into a diocese for better or worse. Like a marriage relationship. And so, if problems are discovered after a priest is incardinated, you just can't get rid of him" (Balboni 1998, p. 182). It is one reason that the church's default mode has been tantamount to protecting the perpetrators; (Reilly 2003, pp. 63-64). ${ }^{22}$ One bishop stated, tellingly, "We were like the military, and the last thing you'd do is 'rat' on someone" (Balboni 1998, p. 185). Catholic doctrine justifies the practice (Parkinson 2013,

22 Ford v. Law 2003, p. 2; State of Minnesota v. the Archdiocese of Saint Paul and Minneapolis. No. 2139124-1 (2015), p. 22. 
p. 21; Tapsell 2014, p. 53). The consequences of that are evident in one striking case in which the bishop actually sent letters to "suspected predatory priests warning them that police were running surveillance on areas where priests were known to solicit children and young men for sex" (Commonwealth of Pennsylvania, Office of Attorney General 2016, p. 61). Bishop Lee Piché, diocese of St. Paul and Minneapolis, commented about a particular case that the diocesan bishop ("gave every possible benefit of the doubt to that priest to not shipwreck a vocation, keep him in the ministry"). ${ }^{23}$ When that is the priority, bishops and other clerical officials ignore warning signs, and instances of outright child sex abuse are reinterpreted as "nothing illegal or immoral" (ibid., p. 8). The sacred bonds between the bishop and priest bias the bishop against even seeing cases as being cases of child sex abuse.

Church doctrines are also the foundation of the sacred beliefs and structures that make clergy child sex abuse particularly traumatizing to the victim. Sexual abuse is often marked by a power differential between perpetrator and victim. Because of what Catholic theology says a priest is and represents, the differential between a priest and his victim is huge, and even more so when the victim is a child (Doyle and Rubino 2004, pp. 561-62; Guido 2008). ${ }^{24}$ The priest has a sacred and paternal role "based on trust and power" (Doyle and Rubino 2004, pp. 562, 601). Catholic children are taught to view the clergy as being "representatives of God, [who] take the place of God, and are deserving of the highest respect and obedience" (Doyle and Rubino 2004, p. 602). One victim said that "We were taught they were Christ's representatives on earth, and that's a direct quote ... A priest would walk in and nuns would bow" (Globe 2002, p. 44). Another, a victim of Father Paul Shanley (Boston archdiocese) stated, "I was terrified of him, of his power. I was terrified of God. I thought he was God" (in Orth 2002). Some priests turned Catholic theology to their advantage by telling their victims that they, the children, had committed a sin and that they would burn in hell if they told anyone else. The victims, in obeying their abusers' instructions, were merely following the dictates of church teachings. One sixteen-year-old victim of a ring of seven priests in Los Angeles who convinced her to regularly have sex with them (and who became pregnant by one) was told by them that "the acts were ethically and religiously permissible." 25

Victims were afraid they would not be believed (Suffolk County Supreme Court Special Grand Jury 2003, pp. 30, 45), and for good reason: they often were not (ibid., pp. 9, 11; Balboni 2011, pp. 60-61; First Judicial District of Pennsylvania County Investigating Grand Jury 2001, p. 8; Statewide Investigating Grand Jury, 40th, Pennsylvania 2018; Suffolk County Supreme Court Special Grand Jury 2003, p. 147). Parents and other close relatives often not merely denied a child's statements about an abusive priest, but punished them for those comments (O'Reilly and Chalmers 2014, p. 14; Suffolk County Supreme Court Special Grand Jury 2003, pp. 10-11). The disbelief that typically accompanies a child's report of being sexually abused by any adult is magnified by the fact that priests were regarded as holy, deserving of respect (Balboni 1998, p. 202). Their sacred status protected them. If other parishioners learned of the reports, many times, including in the years after the Boston scandals, they closed ranks around the priest, not the victim(s) (Suffolk County Supreme Court Special Grand Jury 2003, p. 10; Miller Files n.d., RCALA007056-57). ${ }^{26}$ There was a socially accepted code of silence around clergy child sex abuse. The child was both abused by the priest and by the response of parishioners and church officials. Theologically based norms that prioritized the priest over the laity have resulted in an institution that has been indifferent if not also hostile to victims and their families, and that has failed to prevent further abuse.

23 State of Minnesota v. the Archdiocese of Saint Paul and Minneapolis. No. 2139124-1 (2015), p. 30.

24 Further worsening the impact (and helping to silence the victim), priests sometimes raped or otherwise abused children in the sacred spaces of the church, such as the sanctuary (Commonwealth of Pennsylvania, Office of Attorney General 2016, p. 139).

25 Milla v. Tamayo. Court of Appeal, Second District Division 1 [California] 187 Cal. App 3d 1453. (1987), p. 687.

26 State of Wisconsin v. John Patrick Feeney 2005. Court of Appeals District III. 2005AP333-CR, p. 33. 


\subsection{US Military}

Military doctrine and structure create an environment in which sexual assault by fellow soldiers and/or officers, is a particularly traumatic experience. One victim commented that it is "an incest level of betrayal" (Bernard 2013). The military context emphasizes brotherhood, trust, selflessness and commitment. Marine Commandant Amos has said that "Marines have a sacred obligation to take care of each other" (U.S. Senate Committee on Armed Services 2013, p. 97). One veteran observed, "The military is your family. When you go into battle we're like brothers and sisters. We would die for each other. But these same people will come into your room and rape you, and grope you, and think nothing of it. It's like incest, it's as if your brother sexually assaulted you. Then they act like it never happened. They flat out deny it and if the female were to pursue [charges], the military family says you should keep quiet, you shouldn't pursue this, it was probably your fault anyway" (Lasker 2012). As one victim summarized, "I left the military feeling almost crushingly, the betrayal of my command" (U.S. Senate Committee on Armed Services, Subcommittee on Personnel 2014, p. 15).

As with priests and children, the power of superior officers (including NCOs) over subordinates is pronounced. An assault and rape victim from the Coast Guard describes the relationship in her testimony: "In the environment of instability that boot camp, by design, creates, you are completely vulnerable. The fact of the matter is that being a recruit is as akin to being a prisoner as you can possibly be. From the moment you step off the bus at boot camp, any branch, you follow any order that you are given" (Judicial Proceedings Panel 2014, p. 139). Another victim stated during Congressional testimony that, "you have this incredibly hierarchical system in which nine times out of 10, you are told to stay silent. That is how we are trained in basic training and officer candidate school, not to talk back" (U.S. Senate Subcommittee on Personnel, Committee on Armed Services 2013, p. 29). In a number of cases, victims had "consensual sex" because they were obeying the perpetrator, who was superior in rank. One case is illustrative: the victim, a trainee in service for two months, was "too frightened to protest his [her basic training instructor's] advances in a dark supply room. The defense asked the woman if she resisted [Staff Sergeant Kwinton] Estacio's advances. 'I was too scared to,' she replied. 'Sometimes when somebody is too scared to talk, does that mean that they want to do something?' A military judge found Estacio not guilty of sexually assaulting the trainee, allowing the instructor to face a maximum 1-year prison sentence" for lesser charges (U.S. House of Representatives Committee on Armed Services 2013, p. 41). The power differential leads to the perverse result that rape is not rape. Of the Lackland drill sergeant incidents, General Welsh stated that " 45 of those are cases that we couldn't prosecute under a sexual assault prosecution" (U.S. House of Representatives Committee on Armed Services 2013, p. 12). In essence, the victims hadn't screamed. Assaults meeting the legal criteria for rape or sexual assault are an issue in civil cases as well; the point here is that the military creates a context of unquestioned obedience to superiors, such that the perpetrator may not need to use force or the threat of force to sexually assault someone.

Alleged victims often perceive or experience re-victimization through formal institutional processes and social retaliation (U.S. Senate Committee on Armed Services, Subcommittee on Personnel 2014, p. 7). Investigations are intrusive, and alleged victims run the risk of being prosecuted for collateral infractions such as underage drinking, or of being accused of adultery if the military decides there is not sufficient evidence to prosecute the alleged assailant for sexual assault. In addition, adhering to requirements to maintain "good order and discipline" in their unit, commanders may discipline the victim if the latter begins to falter at their ordinary duties due to consequences of the assault (Judicial Proceedings Panel 2016, p. 24). By dint of the military's command structure and legal code, the victim becomes a problem to be punished. Congressional testimony over the years and other investigations are replete with such cases (U.S. House of Representatives Committee on Armed Services 1994, pp. 26-30; Human Rights Watch 2015).

Victims face extensive pressure not to report having been sexually assaulted. As in the church, reporting is a violation of the code of camaraderie, which is an essential part of how the military operates: "When you're in a team environment, you report something bad that happened to you, you're 
the one responsible for breaking up the team. Even if something bad happened to you, you're still gonna be the 'bad person'" (in Burns et al. 2014, p. 347; cf. U.S. House of Representatives Committee on Armed Services 1994, pp. 19-20). One officer who observed retaliatory behavior and reported it to his superior was told to drop the issue. His command's response captures the institutional view: "you go against one chief, you go against us all" (Human Rights Watch 2015, np). ${ }^{27}$

The sacrificial, almost sacred, nature of what soldiers do on the battlefield seems to predispose commanders to be skeptical of assault accusations and be lenient towards the accused. This is reinforced by the doctrine of "good military character". In 2013, then Chairman of the Joint Chiefs of Staff Army General Martin Dempsey agreed that the battle service record of the accused may work in their favor: "If a perpetrator shows up at a court-martial with a rack of ribbons and has four deployments and a Purple Heart, there is certainly a risk that we might be a little too forgiving of that particular crime" (Torreon 2013, p. 3). Good military character is allowed as a consideration under the UCMJ in determinations of whether to send a case to court-martial or apply disciplinary measures, if any, and until 2014 was allowed in command decisions about court-martial verdicts (DoD 576 Panel 2014, pp. 126, 129). Another victim stated that her "chain of command made it very clear they preferred my attacker, who was a platoon leader, over me and supported him through everything" (Congressional Record November 2013, S8307-8; cf. U.S. Senate Subcommittee on Personnel, Committee on Armed Services 2013, p. 20; Judicial Proceedings Panel 2015, pp. 185-95, 198-213). Numerous reports from victims indicate that they weren't believed, because the accused was a "good soldier", a "devoted husband and father", just as victims of priests weren't believed (Hillman 1999; U.S. Senate Committee on Armed Services 2013, p. 145; Franklin 2013). ${ }^{28}$

\section{Hierarchical Structure and the Incentive to Cover Up}

\subsection{The Church}

The hierarchical structure in which each level of authority has sole authority over his area exacerbates the typical institutional reaction of covering up problems that could lead to scandal. In the Catholic church, reporting cases internally would seem to indicate that bishops are ineffective in dealing with discipline problems and could harm their hopes to be appointed to a more prominent diocese, or avoid being removed. One bishop stated, "An abusing priest was seen as a weak, sinful priest; he was a discipline problem that an effective bishop would be able to handle" (Balboni 1998, p. 24). That reticence to communicate limited information throughout the church, including in the same diocese, about the extent and frequency of clergy sex abuse. It also meant that sex abuse cases were swept under the rug, and claims of and harms to victims ignored or downplayed, at best settled quietly for modest sums with mandatory confidentiality agreements. Victims and their parents understandably did not want their names in the public record. The church took advantage of that, to avoid having to remove permanently or isolate the abusive priest. And those agreements had the effect of preventing parishioners from knowing that their priest had been sexually abusing parish children. As the Boston Globe summarized, those settlements "left no public record of the crime committed by the abusing priest" (Globe 2002, p. 47).

The tendency to cover-up is likely heightened by the fact that bishops are responsible for maintaining the sacred institution, not reforming it (Balboni 1998, p. 157). As one priest bluntly stated, "It's not my responsibility to worry about the boy. My job is to protect the Bishop and the church" (quoted in Suffolk County Supreme Court Special Grand Jury 2003, p. 10; cf. George Deposition 2008, p. 265). In his 2011 deposition, Archbishop Rembert Weakland of Milwaukee acknowledged that the

27 Because both institutions rely on voluntary low-paid labor of those willing to commit their lives to the institution, there are also pressures stemming from potential personnel shortages that may dispose commanders and bishops to be lenient with the accused. In the military, being essential to the mission is a consideration, as well.

28 Baldwin, Celina M. et al. v. Department of Defense, 1:15-Cv-00424, (2015). 
church, at multiple levels, preferred to keep quiet about child sex abuse cases in order to avoid scandal, a typical institutional response: "I can't say it was a practice to hush it up, because I'm not quite sure what is implied there, but there was a certain kind of fear of scandal, and nobody likes to put their dirty laundry out on the line" (Weakland Deposition 2011, p. 70). ${ }^{29}$ At the suggestion that fifteen parishes be notified about a particular priest, Cardinal Roger Mahony of Los Angeles put it more bluntly in 2000, "that really scares the daylights out of me!!" (Baker Files n.d., CALA000387). On occasions when a priest or nun would report to a diocesan official their suspicions about a colleague's behavior, some were told, as one recounted, to "mind his f-ing business" (Suffolk County Supreme Court Special Grand Jury 2003, p. 13), or to "get the hell out of here."30

Of those victims and relatives who did report abuse to Catholic officials, many were motivated to come forward to try to prevent the abuser from creating other victims (e.g., Bistricky Files n.d., DOM021085; Suffolk County Supreme Court Special Grand Jury 2003, p. 14; George Deposition 2008). ${ }^{31}$ However, parents sometimes found that if they came forward, they "were strictly admonished, urged, intimidated, and even threatened with dire consequences if they reported the matter to the police, to the press, or disclosed it in any way" (Doyle and Rubino 2004, p. 586; Lytton 2008, p. 22; Commonwealth of Pennsylvania, Office of Attorney General 2016; O'Reilly and Chalmers 2014, pp. 225-26; Widera Files n.d., ADOM023318). ${ }^{32}$ If other parishioners learned of the reports, many times they closed ranks around the priest, not the victim(s) (Suffolk County Supreme Court Special Grand Jury 2003, p. 10; Miller Files n.d., CALA007056-57). ${ }^{33}$ There was a socially accepted code of silence around clergy child sex abuse, with the result that child was both abused by the priest and by the response of parishioners and church officials.

\subsection{US Military}

Because in the military "[t]he views of subordinates and peers play no role in an officer's advancement; to move up he must only please his superiors" (Yingling 2007), and because there is extensive stress on "good order and discipline", commanders face a dilemma in investigating sexual assault cases and referring them for prosecution. If they go forward, it appears "they are not "handling it at their level,'" and as a result, "they might be passed over for promotions and future command" (Senator Janet Kay Hagan, in (U.S. Senate Committee on Armed Services 2013, p. 124)). Sexual assaults shouldn't be happening, so commanders have an incentive to deter reporting of those that happen. The sexual assaults of trainees by drill instructors at the Army's Aberdeen Proving Grounds are a case in point. Despite lower level commanders knowing of the assaults, they did not notify their own commanders, nor start investigations (U.S. Senate Committee on Armed Services 1997, p. 30; Shadley 2013, p. 122). In the 1997 Senate hearing about Aberdeen, Senator Dirk Kempthorne pointedly asked, "Where was the chain of command while the female trainees were being victimized at Aberdeen?" General Dennis Reimer, then Army Chief of Staff, could only say, "that is one of the issues we are looking hard at" (U.S. Senate Committee on Armed Services 1997, p. 18). Similarly, and despite years of Congressional tinkering with the UCMJ and other policies since the 1996 Aberdeen scandal, when accusations came to light in 2011 that drill sergeants at Lackland Air Force base had been sexually assaulting recruits, local leaders did not take action when they learned of the cases. They delayed reporting up the chain of command (Department of the Air Force [United States] 2012, p. 25;

29 Archbishop Weakland later had to resign as Archbishop when it came to light that he had had a male lover who had threatened to file a sexual assault claim against Weakland, and Weakland had used $\$ 450,000$ of diocese funds to pay off the lover so the latter would not file a lawsuit.

30 Commonwealth of Pennsylvania, Appellant, v. William Lynn, Appellee. Supreme Court of Pennsylvania. 114 A.3d 796 (2015), p. 815.

31 State of Minnesota v. the Archdiocese of Saint Paul and Minneapolis. No. 2139124-1 (2015), pp. 21, $24,36$.

32 (Baker Files n.d.) referenced at http://www.andersonadvocates.com/Documents/priest_files/Widera.pdf.

33 State of Wisconsin v. John Patrick Feeney 2005. Court of Appeals District III. 2005AP333-CR, p. 33. 
U.S. House of Representatives Committee on Armed Services 2013, pp. 1, 9); cf. Congressional Record, Senate 20 November 2013, S8315-6 notes)..$^{34}$

One victim stated, "even if the commander wants to do the right thing, there is often pressure from the top to make it go away or downplay the severity. Discipline problems within a command will usually be reflected on the service record and cost them promotions" (U.S. Senate Committee on Armed Services, Subcommittee on Personnel 2014, p. 8). If anything, Congress, in 2013, by linking promotions to the absence of assaults, has made it even less likely commanders will have an incentive to deal openly with sexual assaults. In noting the tendency to cover-up the issue, a female veteran said, "they've made it seem like you're 'bad' to report it ... It very much seems to be the victim's fault, which is absurd. I can't even tell you how many letters I've seen labeled 'I have zero tolerance of sexual assault in my squadron.' And you know what that says to me? You may have 'zero tolerance'; that means you want 'zero reporting'"' (in Burns et al. 2014, p. 348).

The hierarchical structures have not changed in either institution, nor, to any significant degree, have their internal legal systems under which they operate. This is one of the reasons the church actions on clergy child sex abuse are "strangely disconnected" from Pope Francis' words (Tapsell 2015), and why despite commanders "having all the tools" to deal with sexual assaults, problems in how the institutions respond to cases of sex abuse persist. ${ }^{35}$

\section{Discussion}

\section{The Politics of the Sacred}

In this essay, I have suggested that the sacred status of the Catholic church and the military, perhaps facilitated by gender issues, may affect how they have dealt with internal sexual violence, as well as how they have been treated by public authorities and the public. While other factors are undoubtedly influential, including the highly gendered nature of the two institutions, their sacred status may need more scrutiny. First, sexual assault in the Catholic church and in the US military is said by their leaders to be a violation of the sacred. Yet it is the victim, not the perpetrator, who is perceived as the threat to the institution. This dynamic can be partly accounted for by the strong identification the institutions elicit from individuals (Ashforth et al. 2008; Dukerich Janet et al. 1998). Both institutions demand from their member's full dedication and sacrifice to the institutions above the needs and interests of individuals. When someone exposes grotesque deviance in an organization to which people have committed their lives, the contradiction is accommodated by denying the deviance, and by denying the existence of the victim (Vaughan 1999; Zatman 1993). There may be a "moral disengagement" from responsibility for and efforts to correct "reprehensible conduct" (Bandura 2002, p. 102). The deviance is "normalized". This reaction is likely heightened by the perceived sacred or quasi-sacred status of the institutions because the victim's existence threatens the perception of the divine, on which the status is based. ${ }^{36}$ There is a refusal to empathize with the victim. Instead of defending the one harmed, the one harmed is attacked again. It is the victim who violates the "sacred" by revealing the criminality within the institution.

34 Investigations also found that a climate of fear, and sense of being insulated from higher level commanders contributed to the delay in reporting.

35 In May 2015, Pope Francis himself said parishioners in a Chilean diocese were behaving "foolishly" in protesting against the bishop that Pope Francis had appointed, despite allegations the bishop had covered for a child sex abusing priest, and had himself abused children. In his words, "Osorno [the city in question] suffers, yes, but for being foolish, because they do not open their hearts to what God says, and instead get carried away by all this silliness that everyone speaks of". He had already stated that people "should not be led by the noses by the lefties who orchestrated this whole thing" (Salgado 2015). Later, after reading a letter from one of the victims, he apologized for his insensitivity.

36 An implication is that the higher one rises in the organization, the more likely this will be one's reaction. Thus, Congress requiring review of certain kinds of court-martial actions by high level commanders may be contributing to the problem Congress thought it was solving. 
Second, the presumed sacredness of the institutions has allowed them to perpetuate their behaviors. For the church, particularly in cities with dominant Catholic cultures such as Boston, Cleveland, Cincinnati, and Los Angeles, "Criminal prosecution was rare, because law enforcement and judicial authorities generally deferred to Church authorities to take care of matters" (Doyle and Rubino 2004, p. 554; O'Reilly and Chalmers 2014, pp. 22-23; Commonwealth of Pennsylvania, Office of Attorney General 2016, pp. 82-83). Indeed, they may have owed their jobs to the church. One Catholic official, Monsignor Philip Saylor, testified that "For example, in Johnstown, I would basically pick the mayor; I would pick the chief of police" (Commonwealth of Pennsylvania, Office of Attorney General 2016, p. 103). Prominent officials, such as the county sheriff and chief judge, would sometimes tell the bishop, "you have to do something about these pedophile priests" while leaving the church to decide how to do so (Commonwealth of Pennsylvania, Office of Attorney General 2016, p. 74, cf. p. 104). In a similarly deferential move in 1997, the majority on the Wisconsin Supreme Court noted that "mercy and forgiveness" are "interwoven in the [church's] institution's norms and practices". The Court concluded that because of "this strong belief in redemption, a bishop may determine that a wayward priest can be sufficiently reprimanded through counseling and prayer". ${ }^{37}$ After having used Catholic theology to justify a bishop's actions, the Court nevertheless went on to say that it could not "directly entangle itself in the religious doctrines of faith, responsibility, and obedience" (ibid.,), and thus absolved the bishop and diocese in question from any liability for harms done by a sex-abusing priest.

Public officials in cities and counties across the country deferred to the idea that the church, as a religious institution, was an entity apart that should be trusted to handle its own affairs (O'Reilly and Chalmers 2014, pp. 218-19; Commonwealth of Pennsylvania, Office of Attorney General 2016, p. 70). ${ }^{38}$ In an unfortunate but not uncommon type of case, the police in Altoona, Pennsylvania agreed not to pursue charges when the bishop sent the offending priest out of state for a while, saying they didn't want to cause trouble for the church (Commonwealth of Pennsylvania, Office of Attorney General 2016, pp. 60-62; see also [Pennsylvania] Statewide Investigating Grand Jury, 40th, Pennsylvania 2018, pp. 4, 143). Even after the Boston scandal broke, prosecutors have been cautious. ${ }^{39}$ In the few times when bishops have been criminally charged, they often have taken a stance such as that of Phoenix diocese Bishop Thomas J. O'Brien, who was granted immunity from prosecution for obstruction of justice when he agreed to relinquish his internal authority over sex abuse cases in his diocese. Bishop O'Brien, after he signed the immunity agreement, gave a press conference denying that he had committed a crime or knowingly put children "in harm's way", even though the agreement he signed stated that he had. The county attorney could have sued for breach of the agreement, but did not-again giving the impression that the state defers to the Catholic church (Romney et al. 2003). The O'Brien case is exceptional only in that the bishop was later convicted of an unrelated felony. ${ }^{40}$ Aggressive investigative actions by state and county attorneys in 2018 followed, rather than preceded, public outrage at clerical sex abuse of children.

While one might argue that the deference is due to the legal protections of the First Amendment, courts and prosecutors have shown that the First Amendment is malleable, subject to interpretation, and thus subject to socio-political attitudes. Courts in several states still shield the church from liability through the First Amendment and many courts continue to have an expansive interpretation of the clergy-communicant privilege, with that privilege covering everything from a casual conversation

37 L.L.N. v. J. Gibbs Clauder Supreme Court of Wisconsin No. 95-2084, Wisc. Lexis 55, May 23. (1997), p. 30.

38 There are cases in which priests were investigated, arrested, charged and convicted by civil authorities in the 1970 s and 1980s (e.g., Widera Files n.d.).

39 The legal grounds, as well as court interpretations of those grounds, for criminally charging bishops and other members of the hierarchy varies by state; likewise for dioceses and civil liability claims against them (O'Reilly and Chalmers 2014, pp. 34-38; Formicola 2007, p. 451).

40 Two weeks after the immunity agreement $\mathrm{O}^{\prime}$ Brien killed a man in a hit-and-run accident in Phoenix, and for that felony was given a light sentence of four years probation and 1000 community service hours. 
with a priest to a penitent kneeling and confessing sins in the confessional box with the priest behind a screen, thus protecting Catholic officials from mandatory reporting laws and from those conversations being used in court (Abrams 2003; Arnold 2008; Hamilton 2005; Hamilton 2008).

The separate, special status accorded to US military law has been upheld repeatedly by the US Supreme Court in the past fifty years ( $\mathrm{O}^{\prime}$ Connor 2000). In a 1974 ruling rejecting a habeas corpus appeal by an enlisted man regarding his discharge status and other penalties, the Supreme Court stated, "This Court has long recognized that the military is, by necessity, a specialized society separate from civilian society. We have also recognized that the military has, again by necessity, developed laws and traditions of its own during its long history. The differences between the military and civilian communities result from the fact that 'it is the primary business of armies and navies to fight or be ready to fight wars should the occasion arise'" (quoted in footnote 45; see also U.S. Senate Subcommittee on Personnel, Committee on Armed Services 2013, p. 9). ${ }^{41}$ The Court has, in general, emphasized and based its own reasoning on the view that "the military stands as a society wholly separate from civilian life" (Lichtman 2006, p. 915). In 2011, the U.S. District Court for Eastern Virginia stated, "The 'unique disciplinary structure of the military establishment' is a 'special factor' that counsels against judicial intrusion". ${ }^{42}$ That view was firmly upheld on appeal ${ }^{43}$ and reiterated in another case, also citing Chappell v. Wallace. ${ }^{44}$

While it may be unreasonable to expect the courts to call the military to account when the Constitution makes it clear Congress has the authority to revise the UCMJ, Congress, too, has deferred to the military, citing the military's sacred mission of sacrifice for the nation. Contrary to principal-agent models of military-civilian relations (Feaver 2003), in the issue of the commander's authority over sexual assault cases, there is little tension between efficiency and accountability. Majorities in Congress have largely preferred to let the military handle the problem. As Senator Max Cleland, a veteran, stated to Army officers, "I am hearing from you, I think, that through good command leadership, a reassertion of what is right and what is wrong, a reassertion of basic human dignity, a reassertion of professionalism, you can get on top of this problem and deal with it successfully" (U.S. Senate Committee on Armed Services 1997, p. 29). Senator Lindsey Graham, a veteran, explained as he rejected the proposal to take dispositional authority in serious crimes out of the chain of command, "I do believe that if you are going to give a man or woman the power to send someone in battle and to literally go and die, that we should trust their judgment when it comes to disciplining that unit" (U.S. Senate Subcommittee on Personnel, Committee on Armed Services 2013, p. 69; cf. Congressional Record 6 March 2014, S. 1342). That is a common refrain in Congressional hearings. It is justified with the same refrain the courts use: as Senator Jim Inhofe put it, "We must remember that the military is, by necessity, uniquely separate from the civilian society" (U.S. Senate Committee on Armed Services 2013, p. 6).

Juxtaposing the cases of the church and military illustrate two important features of democratic accountability of sacred institutions, and state sovereignty. First, it shows the importance of the interests and incentives the state and institution have to cooperate or conflict with each other. Organized religions and states are sometimes in conflict, and sometimes not, depending on their goals and their relative power, and the extent to which each needs the other to pursue their own interests (Gill and Keshavarzian 1999; Gill 2008). Similarly, scholars have observed of military and state relations that one of the biggest challenges for the civilian state is to assert its control and authority over the military (Barany 2012; Feaver 2003; Huntington 1957; Wilkinson 2015). Certainly, in the efforts

41 United States ex rel. Toth v. Quarles 1955 in Parker v. Levy 417 U.S. 733 (1974).

42 Cioca v. Rumsfeld, United States District Court for Eastern District of Virginia, 1:11-cv-151-LO-TCB (2011), p. 2, citing Chappell v. Wallace, U.S. 462.

43 Cioca v. Rumsfeld, United States Court of Appeal for the Fourth Circuit. 12-1065 (2013); Dynes v. Hoover 61 U.S. $65,1857$.

44 Klay, Ariana, et al. v. Leon Panetta, Secretary of Defense, et al., US District Court for the District of Columbia, Civil Action No. 12-0350. (2013), p. 10. 
of the church and military to retain control over their own staff and own legal systems, and the state's occasional efforts to hold them accountable for sexual assaults in their midst, we see these tensions play out. This view should also help explain civilian state responses: once the church's mishandling of clergy child sex abuse became a public scandal, politicians and law enforcement officials decided the church had become a political liability. Catholics already had begun voting less reliably for candidates linked to the church (Kellstedt and Guth 2015, pp. 162-64), and after the abuse scandals, they seemed even less likely to follow the church's political suggestions. Elected officials could no longer count on the church delivering the vote, so finally held the church accountable (Commonwealth of Pennsylvania, Office of Attorney General 2016, p. 104). The military, by contrast, since at least 9/11 is an asset to politicians; as the most publicly revered institution in the US, opposing the military is potentially costly to re-election (Pew Research Center 2011, p. 61)..$^{45}$ Sacred status has political roots.

Second, the comparison shows that the state allows some institutions considerable autonomy on grounds that harken back to concepts of corporatism from the Middle Ages in Europe. The state concedes that some entities "have a proper function of their own within the organic whole ... each part has a sphere of natural action that the state should not eliminate" (Stepan 1978, p. 35; cf. Pius X 1910). The corporate status of the institutions has a significant impact on the state's treatment of them. In many places, the Catholic church has been regarded as a distinct entity with its own set of laws and organizational structure, and its own truths, and thus, since humans cannot know truth, the state cannot dominate it, the state can only negotiate with it (Gambetta 1993, pp. 4-6). This view is reflected in the origins of canon law as a parallel legal system (Richardson 2011; Rapp 2005). It is a view that courts and politicians in the US have applied to the church and the military and evident in a statement of the Wisconsin Supreme Court: "Church governance is founded in scripture, modified by reformers over almost two millennia. It would therefore also be inappropriate and unconstitutional for this Court to determine after the fact that the ecclesiastical authorities negligently supervised or retained the defendant Bishop"). ${ }^{46}$

The military may benefit from a similar deference. In the 1950s, political scientist Samuel P. Huntington noted the religious characteristics of the military: "Religion subordinates man to God for divine purposes; the military subordinates man to duty for society's purposes. In its severity, regularity, discipline, the military society shares the characteristics of the religious order. Modern man may well find his monastery in the Army" (Huntington 1957, p. 465). Jonathan Ebel (2015) has picked up on this theme of the religiosity of the concept of the American soldier and the military, noting the devotion and full commitment to the group cause that the individual soldier must exhibit, and describing the sacralization of the soldier's story. Sacred meaning is given to secular acts of members of a secular institution. Kelly Denton-Borhaug documents the extent to which US society has become infused with a "war-culture" of Christian sacrifice and salvation (Denton-Borhaug 2011). The result is that the "protest of U.S. war-culture is interpreted as a kind of heresy, and war itself has become a sacred doctrine and practice" (Denton-Borhaug 2012, p. 129). To quote Senator Chuck Grassley, "I know some Senators will be nervous about the fact that the military is lobbying against this legislation. There is a certain awe that permeates among Senators when people with stars on their shoulders appear among us" (Congressional Record Senate s8317 20 November 2013). Summarizing the view of many in the Senate, Lindsey Graham gave a quasi-transcendent status to commanders' authority by linking it with the founding of the country: "This concept of the authority of the commander goes back to the very beginning of this Nation. Military justice is an essential part of good order and discipline" (Congressional Record 2013, 159/166, 20 November, S8335). Senator John McCain added, "I trust these commanders. I have known thousands of them. I trust them, and I believe in them" (Congressional

45 The relationship between public opinion about the military and Congressional action on sexual assaults is a topic needing further analysis. Congress does hold hearings after scandals, and makes revisions to the UCMJ, without, however, lambasting service-members or the military as an institution.

46 L.L.N. v. J. Gibbs Clauder Supreme Court of Wisconsin No. 95-2084, Wisc. Lexis 55, May 23. (1997), p. 23. 
Record 2013, 159/166, 20 November, S8315-6). Even though she stated she had been sexually assaulted by a superior officer while in the military, Senator McSally advocated letting commanders fix the problem (U.S. Senate Committee on Armed Services 2019, p. 12). Majorities in Congress repeatedly defer to their veteran colleagues and accept the idea that they, as civilians, cannot judge what the military should do-the latter have their own values, rituals and procedures. This deferential view of the separateness, indeed sanctity, of the military, has been buttressed by US courts.

Clergy child sex abuse victims had to compete with priests for sympathy, until through media exposure and inept church responses, the priests and those who supervised them were vilified, and seen as anything but Christ-like. Military sexual assault victims have to compete with fellow soldiers for public sympathy and status (Adelman 2003, pp. 1138-40). It may be that because military sexual assault victims challenge the image of the Christ-like hero soldier, their situation is neglected. The military, not the Catholic church, is now viewed as the repository of the pure and blameless. Typical of many statements by elected officials, Senator Gillibrand, an otherwise fierce critic of the military's handling of sexual assault, stated in her opening remarks on a hearing about sexual assault in the military, "Our best, brightest, and bravest join our Armed Forces for all the right reasons" (U.S. Senate Subcommittee on Personnel, Committee on Armed Services 2013, p. 2; U.S. Senate Committee on Armed Services 2019, p. 99), and President Obama, at a speech at Fort Bragg in 2011, declared, "You're the finest that America has to offer" (Obama 2011). The status of a sacred hero is not one that soldiers necessarily want or identify with (Hartley 2005; Finkel 2013; Richtel 2015). It is, nevertheless, given to them by the American public and elected officials.

There are multiple factors that have affected how the Catholic church and the military in the US have handled cases of sex abuse and assault in their institutions, as well as civilian authorities' responses to them. This paper has drawn attention to the role of the institutions' sacred status, both as it affects those in the institutions and those external to them. More needs to be done to understand how and why officials in the institutions have handled cases as they have over the years (Steinfels 2019) and the conditions under which civil authorities call them to account. Both institutions in the US, and elsewhere, have made changes to how they handle cases, and how they try to prevent them from occurring in the first place; studying the effectiveness of the policies and programs is the next step in a larger research program.

\section{Conclusions}

This paper highlights an issue often overlooked in the media coverage, lawsuits, grand jury investigations and Congressional hearings about clergy child sex abuse and sexual assault in the military: the fact that child sex abuse by religious officials and sexual assault of soldiers by fellow soldiers and officers constitute profound challenges for democracy, as the institutions claim and may be accorded separate and privileged status, beyond the reach of democratic laws and procedures. Organized religions and militaries have long presented challenges to democracies and concepts of citizenship, as religion lays claim to citizens' loyalties and see itself as answering to a higher authority, and as the military has the weaponry and organizational skills to overthrow the democracy and as it conscripts or recruits soldiers who are expected to give up the rights they have as ordinary citizens. As is well known, the US, via the First Amendment, allows considerable freedom from secular laws for those who claim religious exemptions. While the Hobby Lobby Supreme Court ruling allowing religious exemption from employer health insurance mandates and religious exemptions for childhood vaccinations have been in the US news in recent years, less apparent is a de facto religious exemption for child sex abuse in some religious communities (Arnold 2008; Aviv 2014; Fain and Fain 2006). As of 2015, 22 states still exempt religious officials from reporting suspected child sex abuse (Children's Bureau 2016). ${ }^{47}$ With the military, the courts repeatedly defer to the military's

47 More recent data appear not to have been collected by any federal agency. 
separate status and legal code, at most indicating that Congress has the authority to revise the military's statutes. Congress, for its part, keeps yielding to the military's preference to leave the disposition of sexual assault cases in the hands of commanders (Congressional Record CRNDAA16, $2016 \mathrm{np}$ ) As with the courts, Congress justifies this on the basis of the military having a special status and role. These stances are not immutable, as is evident from the fact that courts have developed rationales to allow victims to litigate against the church, from the fact that legislatures in some other countries have restructured military judicial systems, and from the fact that in the 1960s the Supreme Court evinced a skepticism towards the military's separate legal status and in the 1970s did not find that a block to imposing equal opportunity law on the military (O'Connor 2000; Katzenstein 1998, pp. 87-90). Tellingly, those were decades in which, due to the Vietnam War, the military's status was at a low point.

The normative and empirical significance is clear. Revered institutions escape accountability for sexual violence. While there has been considerable public outcry over the failings of the Veterans Administration, the public outcry over the treatment of soldiers who are victims of sexual assault in the military has been muted. ${ }^{48}$ With the repeated failure of Senator Gillibrand's effort to remove discretionary authority over prosecution from the chain of command, public and media attention has shifted to sex abuse at universities. The military may be benefitting from the deference and special status that the Catholic church in cities across America used to have. Once it was seen to have crossed the line on victimizing children, the church lost billions of dollars in legal settlements, and in contributions not given, and has seen membership and attendance in the US and other countries decline. The US military has had its budget cut at times, but not as a penalty for its record in prosecuting sexual assaults, or in changing the culture that fosters such assaults. If anything, the military has achieved a revered status the Catholic church can only wish it could recapture in the US.

In all of this, we should not forget the victims. What comes across strongly is that for many, all they have wanted was, in one victim's words, "two basic things. One was an apology and [another] for the harassment to stop" (U.S. Senate Subcommittee on Personnel, Committee on Armed Services 2013, p. 10). The nature of the two institutions militates against either desire being fulfilled.

Funding: This research was partly funded by a seed grant from the Arizona State University Center for the Study of Religion and Conflict, from a seed grant from the Arizona State University School of Politics and Global Studies Seed Grant program, and from a Fellowship from the Center for Advanced Study in the Behavioral Sciences at Stanford University.

Acknowledgments: I thank Mia Armstrong and James MacDonald for excellent research assistance. My thanks to Jacques Bessy, Jan Breckenridge, Louise Chappell, Annie Cossins, Doug Downey, Lindy Edwards, Andrea Ellner, Tom Frame, Pat Geary, Tony Gill, Magda Hinojosa, Brian Lucas, Frank Brennan, Paul Lewis, Patrick Parkinson, Francis Sullivan, George Thomas, Steve Wilkinson, Wen-hsin Yeh, and a number of other individuals who wish to remain anonymous, and the Comparative Politics Seminar Series at the University of California Berkeley for very helpful discussions, and to Mia Armstrong, Jennet Kirkpatrick, Jason Klocek, Laura Olson, Gary Rumble, Mary Segers and Brad Wright for insightful criticisms and comments on earlier versions of the paper. I thank the Center for Advanced Study in the Behavioral Sciences at Stanford University for writing time, financial support and an unparalleled intellectual and natural environment. Any errors of fact or interpretation, or other problems in the book, are my responsibility.

Conflicts of Interest: The author declares no conflict of interest.

48 Moreover, because many victims are discharged with a diagnosis of "personality disorder", they are not able to access VA benefits for any health conditions caused by the assault (cf. U.S. Senate Subcommittee on Personnel, Committee on Armed Services 2013, pp. 11,16). The VA has a higher bar for victims of sexual assault when assessing whether the victim qualifies for disability compensation (U.S. House of Representatives Subcommittee on Veterans' Affairs 2012; United States Government Accountability Office 2014). 


\section{References and Notes}

Abrams, Norman. 2003. Addressing the Tension between the Clergy-Communicant Privilege and the Duty to Report Child Abuse in State Statutes. Boston College Law Review 44: 1127-16.

Adelman, Madelaine. 2003. The Military, Militarism, and the Militarization of Domestic Violence. Violence Against Women 9: 1118-52. [CrossRef]

Alleman, Lindsy Nicole. 2006. Who is in Charge and Who Should Be? The Disciplinary Role of Commanders in Military Justice Systems. Duke Journal of Comparative and International Law 16: 169-92.

Archdiocese of Milwaukee. n.d. Payments to Priests Accused of Molesting Children. Available online: http://www.andersonadvocates.com/Documents/Key_Milwaukee_Documents/Payments_all.pdf (accessed on 3 May 2016).

Archer, Emerald M. 2013. The power of gendered stereotypes in the US Marine Corps. Armed Forces E Society 39 : 359-91.

Arizona Republic. 2003. Text from O’Brien's News Conference. June 2. Available online: http://www.bishopaccountability.org/az-phoenix/phoenix-agreement-resignation.htm (accessed on 4 May 2015).

Arnold, Julie M. 2008. 'Divine' Justice and the Lack of Secular Intervention: Abrogating the Clergy-Communicant Privilege in Mandatory Reporting Statutes to Combat Child Sexual Abuse. Valparaiso University Law Review 42: 849-903.

Ashforth, Blake E., Spencer H. Harrison, and Kevin G. Corley. 2008. Identification in Organizations: An Examination of Four Fundamental Questions. Journal of Management 34: 325-74. [CrossRef]

Aviv, Rachel. 2014. The Outcast. The New Yorker, November 10, 44-55.

Baker Files. n.d. Archdiocese of Los Angeles Rev. Michael Baker Files. Available online: http://clergyfiles.laarchdiocese.org/files/Baker,\%20Michael.pdf (accessed on 9 September 2017).

Balboni, Barbara Susan. 1998. Through the 'Lens' of the Organizational Culture Perspective: A Descriptive Study of American Catholic Bishops' Understanding of Clergy Sexual Molestation and Abuse of Children and Adolescents. Ph.D. dissertation, Northeastern University, Boston, MA, USA.

Balboni, Jennifer M. 2011. Clergy Sexual Abuse Litigation. Survivors Seeking Justice. Boulder: First Forum Press.

Bandura, Albert. 2002. Selective Moral Disengagement in the Exercise of Moral Agency. Journal of Moral Education 31: 101-19. [CrossRef]

Barany, Zoltan. 2012. The Soldier and the Changing State. Building Democratic Armies in Africa, Asia, Europe and the Americas. Princeton: Princeton University Press.

Benedict, Helen. 2009. The Lonely Soldier. The Private War of Women Serving in Iraq. Boston: Beacon Press.

Bernard, Michelle. 2013. With women in combat, will military finally address epidemic of sexual assault? Washington Post, January 24.

Berry, Jason. 1992. Lead Us Not Into Temptation. Catholic Priests and the Sexual Abuse of Children. New York: Doubleday.

Bistricky Files. n.d. Archdiocese of Milwaukee. Available online: http://www.andersonadvocates.com/Documents/ priest_files/Bistricky.pdf (accessed on 5 June 2017).

Burns, Brigit, Kate Grindlay, Kelsey Holt, Ruth Manski, and Daniel Grossman. 2014. Military Sexual Trauma Among US Servicewomen During Deployment: A Qualitative Study. American Journal of Public Health 104: 345-49. [CrossRef] [PubMed]

Carlson, John D. 2008. Winning souls and minds: The military's religion problem and the global war on terror. Journal of Military Ethics 7: 85-101. [CrossRef]

Carroll, Chris, and John Vandiver. 2014. Army's top sexual assault prosecutor suspended after assault allegation. Stars and Stripes, March 6.

Cartor, Pam, Peter Cimbolic, and Jennifer Tallon. 2008. Differentiating Pedophilia from Ephebophilia in Cleric Offenders. Sexual Addiction \& Compulsivity 15: 311-19.

Catholic Church. 1999. Catechism of the Catholic Church. London: Geoffrey Chapman.

Chappell, Louise. 2014. 'New,' ‘Old,' and 'Nested' Institutions and Gender Justice Outcomes: A View from the International Criminal Court. Politics E Gender 10: 572-94.

Children's Bureau. 2016. Clergy as Mandatory Reporters of Child Abuse and Neglect. Available online: https://www.childwelfare.gov/topics/systemwide/laws-policies/statutes/clergymandated/ (accessed on 3 March 2017). 
Cohen, Dara Kay, and Ragnhild Nordhås. 2015. Do States delegate sexual violence to militias? Patterns of sexual violence in recent armed conflicts. Journal of Conflict Resolution 59: 877-98. [CrossRef]

Commission of Investigation. 2010. Report into the Catholic Diocese of Cloyne. Republic of Ireland. Available online: http://www.justice.ie/en/JELR/Pages/Cloyne-Rpt (accessed on 15 July 2015).

Commonwealth of Pennsylvania, Office of Attorney General. 2016. A Report of the Thirty-Seventh Statewide Investigating Grand Jury. March 1. Available online: https:/www.attorneygeneral.gov/uploadedFiles/ MainSite/Content/Related_Content/PressReleases/GJ\%20Diocese\%20Report.pdf (accessed on 7 July 2016).

Cossins, Anne. 2000. Masculinities, Sexualities and Child Sexual Abuse. The Hague: Kluwer Law International.

County Investigating Grand Jury XXIII. 2011. First Judicial District of Pennsylvania. 0009901-2008, C-14. Available online: http://www.phila.gov/districtattorney/pdfs/clergyabuse2-finalreport.pdf (accessed on 4 April 2016).

Cozzens, Donald B. 2002. Sacred Silence: Denial and crisis in the Church. Collegeville: Liturgical Press.

Crozier, Michel. 1964. The Bureaucratic Phenomenon. Chicago: University of Chicago Press.

De Fuentes, Nanette. 2004. Clergy Sexual Misconduct Oversight Review Boards. In Sin against the Innocents. Sexual Abuse by Priests and the Role of the Catholic Church. Edited by Thomas G. Plante. Westport: Praeger, pp. 47-60.

Dempsey, Jason K. 2010. Our Army. Soldiers, Politics, and American Civil-Military Relations. Princeton: Princeton University Press.

Denton-Borhaug, Kelly. 2011. U.S. War-Culture, Sacrifice and Salvation. Sheffield: Equinox.

Denton-Borhaug, Kelly. 2012. Beyond Iraq and Afghanistan: Religion and Politics in United States War-Culture. Dialog 51: 125-34. [CrossRef]

Department of Defense [United States]. 2010. Demographics 2009. Profile of the Military Community. Available online: http://download.militaryonesource.mil/12038/MOS/Reports/2009-Demographics-Report. pdf (accessed on 4 April 2017).

Department of Defense Sexual Assault Prevention and Response [United States]. 2015. Department of Defense Annual Report on Sexual Assault in the Military Fiscal Year 2014. Available online: http://sapr.mil/ public/docs/reports/FY14_Annual/FY14_DoD_SAPRO_Annual_Report_on_Sexual_Assault.pdf (accessed on 4 April 2017).

Department of the Air Force [United States]. 2012. Command Directed Investigation: Developing America's Airmen: A Review of Air Force Enlisted Training. August 22 [redacted]. Available online: https://timemilitary. files.wordpress.com/2012/11/afd-121114-057.pdf (accessed on 4 April 2017).

DoD 576 Panel. 2014. Response Systems to Adult Sexual Assault Crimes Panel. In Report of the Response Systems to Adult Sexual Assault Crimes Panel. Washington: Department of Defense, Available online: http: //responsesystemspanel.whs.mil/public/docs/Reports/00_Final/RSP_Report_Final_20140627.pdf (accessed on 10 August 2016).

Doig, Jameson W., Douglas E. Phillips, and Tycho Manson. 1984. Deterring illegal behavior by officials of complex organizations. Criminal Justice Ethics 3: 27-56. [CrossRef]

Doyle, Michael. 2012. Tough talk by Marine Commandant James Amos complicates sexual-assault cases. McClatchy Newspapers, September 13.

Doyle, Thomas P., and Stephen C. Rubino. 2004. Catholic Clergy Sexual Abuse Meets the Civil Law. Fordham Urban Law Review 31: 549-616.

Dukerich Janet, M., Robert Kramer, Judi McLean Parks, and David Whetton. 1998. The dark side of organizational identification. In Identity in Organizations: Building Theory through Conversations. Edited by David A. Whetten, Paul C. Godfrey and Paul Godfrey. Thousand Oaks: Sage, pp. 245-56.

Durbach, Andrea, and Louise Chappell. 2014. Leaving Behind the Age of Impunity: Victims of Gender Violence and the Promise of Reparations. International Feminist Journal of Politics 16: 543-62. [CrossRef]

Ebel, Jonathan H. 2015. G.I. Messiahs. Soldiering, War, and American Civil Religion. New Haven: Yale University Press.

Ellner, Andrea. 2015. The Ethics of Inclusion: Gender Equality, Equal Opportunity and Sexual Assault in the Australian, British, Canadian and US Armed Forces. In Routledge Handbook of Military Ethics. Edited by George Lucas. Abingdon: Routledge, pp. 300-18.

Fain, Constance Frisby, and Herbert Fain. 2006. Sexual Abuse and the Church. Thurgood Marshall Law Review 31: 209-38. First published 2005.

Feaver, Peter. D. 2003. Armed Servants. Agency, Oversight, and Civil-Military Relations. Cambridge: Harvard University Press. 
Feaver, Peter D., and Richard H. Kohn, eds. 2001. Soldiers and Civilians. The Civil-Military Gap and American National Security. Cambridge: MIT Press.

Finkel, David. 2013. Thank You for Your Service. New York: Farrar, Straus \& Giroux.

First Judicial District of Pennsylvania County Investigating Grand Jury. 2001. Report of the Grand Jury September 26. Available online: http://www.bishop-accountability.org/reports/2003_09_25_First_Philadelphia_Grand_ Jury_Report.pdf (accessed on 16 July 2015).

Formicola, Jo Renee. 2004. The Vatican, the American Bishops, and the Church-State Ramifications of Clerical Sexual Abuse. Journal of Church and State 46: 479-502. [CrossRef]

Formicola, Jo Renee. 2007. The Further Legal Consequences of Catholic Sexual Abuse. Journal of Church and State 49: 445-65. [CrossRef]

Formicola, Jo Renee. 2011. Catholic Clerical Sexual Abuse: Effects on Vatican Sovereignty and Papal Power. Journal of Church and State 53: 523-44. [CrossRef]

Formicola, Jo Renee. 2014. Clergy Sexual Abuse: How the Crisis Changed US Catholic Church-State Relations. New York: Palgrave-MacMillan.

Formicola, Jo Renee. 2016. The Politics of Clerical Sexual Abuse. Religions 7: 9. [CrossRef]

Franklin, Lt. General Craig A. 2013. Letter to Secretary of the Air Force Donley. Available online: https://www.scribd.com/doc/135203535/Air-Force-General-explains-why-he-overturnedthe-decision-in-sexual-assault-case (accessed on 22 July 2016).

Gambetta, Diego. 1993. The Sicilian Mafia. The Business of Private Protection. Cambridge: Harvard University Press.

Gamm, Gerald. 1999. Urban Exodus. In Why the Jews Left Boston and the Catholics Stayed. Cambridge: Harvard University Press.

George Deposition. 2008. Deposition. January 30. Available online: http://www.andersonadvocates.com/ Documents/Key_Chicago_Documents/Cardinal\%20George\%20Depo.pdf (accessed on 4 April 2017).

Gill, Anthony. 2008. Political Origins of Religious Liberty. New York: Cambridge University Press.

Gill, Anthony, and Arang Keshavarzian. 1999. State Building and Religious Resources: An Institutional Theory of Church-State Relations in Iran and Mexico. Politics E Society 27: 431-65.

Globe, Boston. 2002. Betrayal. The Crisis in the Catholic Church. Boston: Little, Brown and Company.

Goffman, Erving. 1961. Asylums. New York: Random House.

Guido, Joseph J. 2008. A Unique Betrayal: Clergy Sexual Abuse in the Context of the Catholic Religious Tradition. Journal of Child Sexual Abuse 17: 255-69. [CrossRef]

Hamilton, Marci. 2005. God vs. the Gavel. Religion and the Rule of Law. New York: Cambridge University Press.

Hamilton, Marci. 2008. Justice Denied: What America Must Do to Protect Its Children. New York: Cambridge University Press.

Hartley, Jason Christopher. 2005. Just Another Soldier. A Year on the Ground in Iraq. New York: Harper Collins Publisher.

Hassner, Ron E. 2009. War on Sacred Grounds. Ithaca: Cornell University Press.

Heed, Peter W., N. William Delker, and James D. Rosenberg. 2003. Report on the Investigation of the Diocese of Manchester. March 3. Manchester: Office of the Attorney General. Available online: http://www.bishopaccountability.org/resources/resource-files/reports/NewHampshireAGReport.pdf (accessed on 22 July 2016).

Henry Files. 1997. Archdiocese of Los Angeles Rev. Richard Henry Files. Available online: http://clergyfiles.laarchdiocese.org/files/Henry,\%20Richard.pdf (accessed on 3 March 2017).

Hillman, Elizabeth Lutes. 1999. The 'Good Soldier' Defense: Character Evidence and Military Rank at Courts-Martial. Yale Law Journal 108: 879-911. [CrossRef]

Human Rights Watch. 2015. Embattled: Retaliation Against Sexual Assault Survivors in the US Military. Available online: https://www.hrw.org/report/2015/05/18/embattled/retaliation-against-sexual-assault-survivors-usmilitary (accessed on 22 July 2016).

Hungerman, Daniel. 2013. Substitution and Stigma: Evidence on Religious Competition from the Catholic Sex-Abuse Scandal. The American Economic Journal: Economic Policy 5: 227-53.

Huntington, Samuel P. 1957. The Solider and the State: Theory and Politics of Civil-Military Relations. Cambridge: Harvard University Press.

Irish Catholic Bishops' Advisory Committee on Child Sexual Abuse by Priests and Religious. 1996. Child Sexual Abuse. Framework for a Church Response. Dublin: Veritas. 
John Jay College of Criminal Justice. 2004. The Nature and Scope of Sexual Abuse of Minors by Catholic Priests and Deacons in the United States, 1950-2002. Washington: United States Conference of Catholic Bishops.

John Jay College Research Team. 2011. The Causes and Context of the Sexual Abuse of Minors by Catholic Priests in the United States, 1950-2010. Washington: United States Conference of Catholic Bishops.

Joint Service Committee on Military Justice. 2012. Manual for Courts-Martial United States 2012. Washington: USAPD.

Judicial Proceedings Panel. 2014. Judicial Proceedings Since Fiscal Year 2012 Amendments Panel. Transcript. Sept. 19. Washington: Neal R. Gross Court Reporters and Transcribers.

Judicial Proceedings Panel. 2015. Prevention and Response to Retaliation Against Victims of Sexual Assault Crimes. Transcript. May 19. Washington: Neal R. Gross and Co., Inc.

Judicial Proceedings Panel. 2016. Retaliation Related to Sexual Assault Offenses. Available online: http: //jpp.whs.mil/Public/docs/08-Panel_Reports/04_JPP_Retaliation_Report_Final_20160211.pdf (accessed on 14 December 2018).

Katzenstein, Mary Fainsod. 1998. Faithful and Fearless: Moving Feminist Protest inside the Church and Military. Princeton: Princeton University Press.

Katzenstein, Mary Fainsod, and Elizabeth Reppy, eds. 1999. Beyond Zero Tolerance: Discrimination in Military Culture. Lanham: Rowman \& Littlefield.

Keenan, Marie. 2012. Child Sexual Abuse \& the Catholic Church. Oxford: Oxford University Press.

Kellstedt, Lyman A., and James L. Guth. 2015. Religious Groups as a Polarizing Force. In Polarized Politics: The Impact of Divisiveness in the US Political System. Edited by in William Crotty. Boulder: Lynne Rienner, pp. 157-86.

Lasker, John. 2012. The Tragic Case of Maria Lauterbach. Dayton City Paper. April 3. Available online: http://www.daytoncitypaper.com/the-tragic-case-of-maria-lauterbach-2/\#sthash.XehJQyiP.dpuf (accessed on 10 October 2015).

Law Library of Congress. 2013. Military Justice: Adjudication of Sexual Offenses. Australia, Canada, Germany, Israel, United Kingdom. LL File No. 2013-009638. Washington: Global Research Center.

Legal Information Institute. n.d. Cornell University Law School. 10 U.S. Code 20. Art. 120. Rape and Sexual Assault Generally. Available online: https://www.law.cornell.edu/uscode/text/10/920 (accessed on 8 November 2015).

Lichtman, Steven B. 2006. The Justices and the Generals: A Critical Examination of the U.S. Supreme Court's Tradition of Deference to the Military, 1918-2004. Maryland Law Review 65: 917-66.

Lincoln, Bruce. 2003. Holy Terrors. Thinking about Religion after 9/11. Chicago: University of Chicago Press.

Lisak, David, and Paul M. Miller. 2002. Repeat Rape and Multiple Offending among Undetected Rapists. Violence and Victims 17: 73-84. [CrossRef]

Lytton, Timothy D. 2008. Holding Bishops Accountable. How Lawsuits Helped the Catholic Church Confront Clergy Sexual Abuse. Cambridge: Harvard University Press.

Miller Files. n.d. Archdiocese of Los Angeles Rev. George Miller Files. Available online: http://clergyfiles.laarchdiocese.org/files/Miller,\%20George.pdf (accessed on 9 January 2018).

Ministère de la Défense. 2014. Rapport de la Mission D'enquête sur les cas de Harcèlement, Agressions et Violences Sexuels dans les Armées. Paris: Contrôle Général des Armées.

Minnesota Public Radio. 2014. Betrayed by Silence. Available online: http://minnesota.publicradio.org/collections/ catholic-church/ (accessed on 1 August 2015).

Morris, Lawrence J. 2010. Military Justice. A Guide to the Issues. Santa Barbara: Praeger.

Nash, Patrick J. 2019. The Never Ending Story? Or, Does the Roman Catholic Church Remain Vulnerable to Charges of Improper Handling of Clergy Child Sex Abuse? Oxford Journal of Law and Religion, rwy053. [CrossRef]

National Catholic Reporter Editorial Staff. 2019. Vatican's summit on abuse gets a mixed verdict. National Catholic Reporter, February 28.

Neustein, Amy, and Michael Lesher. 2008. A Single-Case Study of Rabbinic Sexual Abuse in the Orthodox Community. Journal of Child Sexual Abuse 17: 270-80. [CrossRef] [PubMed]

Nienstedt, John. 2014. Deposition of Archbishop John Nienstedt. St. Paul: Affiliated Court Reporters. Available online: https://www.documentcloud.org/documents/1337309-nienstedt-deposition.html (accessed on 15 July 2015). 
O'Connor, John F. 2000. The Origins and the Application of the Military Deference Doctrine. Georgia Law Review 35: 161-311.

O'Reilly, James T., and Margaret S. P. Chalmers. 2014. The Clergy Sex Abuse Crisis and the Legal Responses. New York: Oxford University Press.

Obama, Barack. 2011. Remarks by the President and First Lady on the End of the War in Iraq. Available online: http://www.whitehouse.gov/the-press-office/2011/12/14/remarks-president-and-first-lady-end-wariraq (accessed on 9 January 2018).

Office of People Analytics. 2017. Workplace and Gender Relations Survey of Active Duty Members. Overview Report; OPA 2016-050; Alexandria: Office of People Analytics, Defense Research, Survey and Statistics Center.

Orth, Maureen. 2002. Vanity Fair. Unholy Communion. August. Available online: http://www.vanityfair.com/ culture/features/2002/08/orth200208 (accessed on 10 January 2018).

Parkinson, Patrick. 2013. The Smith Lecture 2013. Child Sexual Abuse and the Churches: A Story of Moral Failure? Sydney: Camperdown University of Sydney.

Pew Research Center. 2011. War and Sacrifice in the Post-9/11 Era. Washington: Pew SOcial \& Demographic Trends.

Pius X. 1910. Quam Singulari. Available online: http://www.papalencyclicals.net/Pius10/p10quam.htm (accessed on 10 January 2018).

RAND. 2015. Sexual Assault and Sexual Harassment in the US Military. Available online: http://www. rand.org/content/dam/rand/pubs/research_briefs/RB9800/RB9841/RAND_RB9841.pdfRAND (accessed on 5 June 2017).

Rapp, Claudia. 2005. Holy Bishops in Late Antiquity. The Nature of Christian Leadership in an Age of Transition. Berkeley: University of California Press.

Reilly, Thomas. 2003. The Sexual Abuse of Children in the Roman Catholic Archdiocese of Boston. Boston: Office of the Attorney General, Available online: http://www.bishop-accountability.org/resources/resource-files/reports/ ReillyReport.pdf (accessed on 16 September 2016).

Richardson, William. 2011. The Presumption of Innocence in Canonical Trials of Clerics Accused of Child Sexual Abuse. An Historical Analysis of the Current Law. Leuven: Peeters.

Richtel, Matt. 2015. Please Don't Thank Me for My Service. New York Times, February 21.

Romney, Rick, Thomas J. O'Brien, and the Roman Catholic Diocese of Phoenix. 2003. Agreement, 3 May 2003. p. 3. Available online: http://www.cbsnews.com/htdocs/pdf/bishopagreement.pdf;http://www.bishopaccountability.org/az-phoenix/phoenix-agreement-resignation.htm (accessed on 12 July 2015).

Royal Commission on Institutional Responses to Child Sex Abuse. 2017. Final Report. Religious Institutions. Sydney: Royal Commission on Institutional Responses to Child Sex Abuse, vol. 16.

Rumble, Gary A., Melanie McKean, and Dennis Pearce. 2011. Report of the Review of Allegations of Sexual and other Abuse in Defence. Facing the Problems of the Past. Sydney: Department of Defence, vol. 1.

Rustico, Greg. 2016. Overcoming Overcorrection. Towards Holistic Military Sexual Assault Reform. Virginia Law Review 102: 2027-74.

Salgado, Soli. 2015. Francis defends bishop accused of concealing sex abuse. National Catholic Reporter, October 8.

Schenck, Lisa M. 2014. Informing the Debate About Sexual Assault in the Military Services: Is the Department of Defense Its Own Worst Enemy? Ohio State Criminal Law Journal 11: 579-671.

Seck, Hope Hodge. 2014. Court Overturns 18-year rape sentence tainted by Heritage Brief. Marine Corps Times, May 24.

Senander, Angela. 2017. Beyond Scandal: Creating a Culture of Accountability in the Catholic Church. Journal of Business Ethics 146: 859-67. [CrossRef]

Shadley, Robert D. 2013. The GAMe. Unraveling a Military Sex Scandal. Edina: Beaver's Pond Press.

Slavin, Erik. 2013. Judge: Obama sex assault comments 'unlawful command influence.'. Stars and Stripes, June 14.

Stander, Valerie A., and Cynthia J. Thomsen. 2016. Sexual Harassment and Assault in the U.S. Military: A Review of Policy and Research Trends. Military Medicine 181/1: 20-27. [CrossRef] [PubMed]

Statewide Investigating Grand Jury, 40th, Pennsylvania. 2018. Report I, Interim-Redacted. Available online: https://www.documentcloud.org/documents/4756977-40th-Statewide-Investigating-Grand-JuryInterim.html (accessed on 13 August 2018).

Steinfels, Peter. 2019. Vehemently Misleading. The Pennsylvania Grand Jury Report is Not What It Seems. Commonweal, January 25, 13-26.

Stepan, Alfred. 1978. The State and Society, Peru in Comparative Perspective. Princeton: Princeton University Press. 
Suffolk County Supreme Court Special Grand Jury. 2003. Grand Jury Report. May 6. Available online: http: //www.bishop-accountability.org/reports/2003_02_10_SuffolkGrandJury/Suffolk_Full_Report.pdf. (accessed on 15 July 2016).

Tapsell, Kieran. 2014. Potiphar's Wife. The Vatican's Secret and Child Sexual Abuse. Adelaide: ATF Press.

Tapsell, Kieran. 2015. The Strange Disconnect between Pope Francis' words and actions about sex abuse. National Catholic Reporter, October 1.

Torreon, Barbara Salazar. 2013. Military Sexual Assault: Chronology of Activity in Congress and Related Resources; Washington: Congressional Research Service, July 30.

Truth, Justice, and Healing Council. 2016. Emerging Themes: A snapshot of Approaches Taken by Church Authorities in Australia to Formation, Governance, Legal and Policy Issues. vol. 4. no copyright information.

Truth, Justice, and Healing Council. 2018a. Where from and Where to: The Truth, Justice and Healing Council, the Royal Commission and the Catholic Church in Australia. vol. 1. no copyright information.

Truth, Justice, and Healing Council. 2018b. The Royal Commission's Recommendations and Responses from the Truth, Justice and Healing Council. vol. 2. no copyright information.

Truth, Justice, and Healing Council. 2018c. What We Have Done: An Activity Report from the Truth, Justice and Healing Council. vol. 3. no copyright information.

U.S. Army Inspector General Agency. 2013. Report of Investigation Case 13-019. Available online: http://apps.washingtonpost.com/g/page/world/report-of-investigation-by-the-army-inspectorgeneral-into-maj-gen-michael-t-harrison-sr/961/ (accessed on 12 June 2018).

U.S. House of Representatives Committee on Armed Services. 1994. Sexual Harassment of Military Women and Improving the Military Complaint System, March 9.

U.S. House of Representatives Committee on Armed Services. 2013. A Review of Sexual Misconduct of Basic Training Instructors at Lackland Air Force Base, January 23.

U.S. House of Representatives Military Personnel and Compensation Subcommittee and Defense Policy Panel of the Committee on Armed Services. 1992. Women in the Military: The Tailhook Affair and the Problem of Sexual Harassment, September 14.

U.S. House of Representatives Subcommittee on Veterans' Affairs. 2012. Invisible Wounds: Examining the Compensation Benefits Process for Victims of Military Sexual Trauma, July 18.

U.S. Senate Committee on Armed Services. 1997. Army Sexual Harassment Incidents at Aberdeen Proving Ground and Sexual Harassment Policies within the Department of Defense, February 4.

U.S. Senate Committee on Armed Services. 2013. Pending Legislation Regarding Sexual Assaults in the Military Hearing before the Committee, June 4.

U.S. Senate Committee on Armed Services. 2019. Hearing to Receive Testimony on the Military Services' Prevention of and Response to Sexual Assault. March 6. Available online: https://www.armed-services. senate.gov/imo/media/doc/19-21_03-06-19.pdf (accessed on 16 April 2019).

U.S. Senate Committee on Armed Services, Subcommittee on Personnel. 2014. The Relationships between Military Sexual Assault, Post-Traumatic Stress Disorder and Suicide, and on Department of Defense and Department of Veterans Affairs Medical Treatment and Management of Victims of Sexual Trauma, February 26.

U.S. Senate Subcommittee on Personnel, Committee on Armed Services. 2013. Hearing to Receive Testimony on Sexual Assaults in the Military, March 13.

U.S. Senator Kirsten Gillibrand. 2015. One Year after Earlier NDAA Reforms, Status quo Unchanged. Available online: http://www.gillibrand.senate.gov/imo/media/doc/Infographic.pdf (accessed on 22 July 2016).

United Nations Committee on the Rights of the Child. 2014. Concluding Observations on the Second Periodic Report of the Holy See. Geneva: United Nations.

United States Government Accountability Office. 2011. Military Justice. Oversight and Better Collaboration Needed for Sexual Assault Investigations and Adjudications; Washington: GAO.

United States Government Accountability Office. 2014. Military Sexual Trauma; Washington: GAO.

Vatican. 1983. Code of Canon Law. Available online: http://www.vatican.va/archive/ENG1104/_INDEX.HTM (accessed on 8 July 2016).

Vaughan, Diane. 1996. The Challenger Launch Decision. Risky Technology, Culture, and Deviance at NASA. Chicago: University of Chicago Press.

Vaughan, Diane. 1999. The Dark Side of Organizations: Mistake, Misconduct, and Disaster. Annual Review of Sociology 25: 271-305. [CrossRef] 
Waters, Ian. 2016. The Law of Secrecy in the Latin Church. The Canonist 7: 75-87.

Weakland Deposition. 2011. Archbishop Rembert G. Weakland, 10/21/11. United States Bankruptcy Court for the Eastern District of Wisconsin. Case 11-20059-SVK.

Weigley, Russell F. 2004. The American Military and the Principle of Civilian Control from McClellan to Powell. The Journal of Military History 57/5: 27-58. [CrossRef]

Whitlock, Craig. 2014. Army general disciplined over mishandling of sexual-assault case in Japan. Washington Post, April 22.

Whitlock, Craig. 2015. In the war against sexual assault, the Army keeps shooting itself in the foot. Washington Post, December 19.

Whitlock, Craig. 2017. How the military handles sexual assault cases behind closed doors. Washington Post, September 30.

Widera Files. n.d. Available online: http://www.andersonadvocates.com/Documents/priest_files/Widera.pdf (accessed on 4 June 2018).

Wilkinson, Steven I. 2015. Army and Nation. The Military and Indian Democracy Since Independence. Cambridge: Harvard University Press.

Wilson, James Q. 1989. Bureaucracy. What Government Agencies Do and Why They Do It. New York: Basic Books.

Winthrop, William. 1920. Military Law and Precedents; Washington: Government Printing Office, First published 1886.

Wood, Elisabeth Jean. 2009. Armed Groups and Sexual Violence: When Is Wartime Rape Rare? Politics and Society 37: 131-61. [CrossRef]

Wood, Elisabeth Jean, and Nathaniel Toppelberg. 2017. The persistence of sexual assault within the US military. Journal of Peace Research 54: 620-33. [CrossRef]

Yingling, Lt. Col. Paul. 2007. Armed Forces Journal. May 1. Available online: http://www.armedforcesjournal. com/a-failure-in-generalship/ (accessed on 12 July 2016).

Zatman, Gerald. 1993. Knowledge disavowal in organizations. In Producing Useful Knowledge for Organizations. Edited by Ralph H. Kilmann. San Francisco: Jossey-Bass, pp. 173-87.

(C) 2019 by the author. Licensee MDPI, Basel, Switzerland. This article is an open access article distributed under the terms and conditions of the Creative Commons Attribution (CC BY) license (http://creativecommons.org/licenses/by/4.0/). 